\title{
O INDIANISMO REVISITADO: \\ A AUTORIA FEMININA E A LITERATURA BRASILEIRA DO SÉCULO XIX
}

\author{
Anselmo Peres Alós*
}

RESUMO: Ce travail se propose de repérer et d'identifier l'occurrence du maintien et/ou des ruptures des représentations de la femme et de l'Indien dans les récits littéraires, à partir du roman indigéniste écrit par femmes. Fondé sur une perspective qui rapproche les concepts de race, genre, idéologie, nation et sujet, ce travail porte sur deux romans indigénistes écrits par femmes qui ont été laissés en marge du canon, en les rapprochant des textes indigénistes canoniques. Le présent travail établit aussi des rapports intertextuelles et il propose, enfin, une lecture de ces textes non-canoniques, avec une analyse des questions concernant la problématique de la représentation de race et de genre au sein de la littérature brésilienne du XIXe siècle.

PALAVRAS-CHAVE: Literatura Brasileira. Romantismo. Raça. Gênero. Nação. Autoria feminina no século $X I X$.

\section{INTRODUÇÃO}

Uma reflexão sobre a produção das escritoras brasileiras do século XIX é tanto pertinente quanto necessária, na medida em que a exclusão da autoria feminina da historiografia literária coincide com o momento no qual o desenvolvimento de idéia de uma literatura brasileira está atrelado a um projeto de construção política da identidade nacional. A negação da legitimidade autoral aos textos escritos por mulheres vem denunciar, desta forma, a exclusão da participação feminina na produção de uma identidade cultural brasileira. A partir das primeiras reflexões sobre as obras oitocentistas de autoria de mulheres, na tentativa de averiguar até que ponto D. Narcisa de Villar (romance de cunho indianista escrito por Ana Luísa de Azevedo Castro em 1865) mantinha e até que ponto rompia com o discurso indianista canônico, deparei-me com um outro texto - também de autoria feminina - datado de 1861-1862: trata-se do romance Gupeva, escrito por Maria Firmina dos Reis. A partir da leitura desses dois romances surgiram importantes questões norteadoras para este trabalho: de que forma os romances indianistas escritos por mulheres colaboram com o projeto indianista da construção de uma identidade nacional brasileira, e de que forma elas observam e representam o índio e a mulher, enquanto sujeitos sociais deslegitimados, marginalizados e silenciados no programa de construção da nação enquanto comunidade imaginada?

Praticamente durante toda a produção literária do período romântico, mas em especial durante a fase indianista, a mulher tem espaço apenas com objeto representado ii, e não como um sujeito autoral capaz de produzir representações culturais, de forma a colaborar com o projeto de construção de uma identidade coletiva sob a égide do nacional. Assim, o principal intuito deste estudo pode ser definido como o mapeamento e a identificação da manutenção e/ou das rupturas estabelecidas nas representações canônicas, a partir dos escritos indianistas de autoria feminina. Este trabalho lança mão, desta forma, da historiografia, do comparatismo e da crítica literária, na medida em que: a) resgata dois romances indianistas de autoria feminina que foram deixados à margem do cânone iii; b) aproxima-os de textos indianistas canônicos, estabelecendo relações intertextuais e, finalmente, c) propõe uma leitura desses textos não-canônicos, interpretando-os como alegorias que levantam questões relativas à problemática da representação de raça e de gênero dentro da literatura brasileira do século XIX.

Optei por não fazer uma revisão exaustiva do que a crítica e a historiografia já canonizadas afirmam sobre o indianismo na literatura brasileira. Dadas as dimensões deste trabalho, o qual não visa mapear todo o pensamento crítico sobre a literatura indianista, mas sim incorporar textos marginais a um corpus literário consolidado e, de certa forma, fossilizado sobre si mesmo, opta-se por explicitar as concepções teóricas utilizadas para basilar as reflexões aqui apresentadas, detendo-se aqui sobre essas obras indianistas praticamente desconhecidas, visto que o foco de interesse no presente momento é dar visibilidade às obras dessas escritoras. Especulações mais aprofundadas sobre os pressupostos românticos e a inserção do indianismo na série literária são com certeza muito pertinentes, mas não estão aqui contemplados, exceto quando elucidativos de questões suscitadas pelos textos em questão.

Na primeira parte deste estudo, procuro explicitar as categorias analíticas que serão operacionalizadas por ocasião da análise dos romances. O aporte teórico utilizado provém de áreas distintas do conhecimento,

\footnotetext{
* Anselmo Peres Alós é doutorando em Estudos de Literatura/Literatura Comparada pelo Programa de Pós-Graduação em Letras da Universidade Federal do Rio Grande do Sul.
} 
interconectando conceitos provenientes de áreas que não apenas a teoria ou a historiografia literária. Tal ponte é estabelecida a partir das reflexões de pensadores pós-coloniais como Homi K. Bhabha e Edward W. Said, que apontam para a indissociabilidade entre o cultural e o político. A articulação entre tais conceitos e o trabalho de análise literária propriamente dita acontece por ocasião da segunda e terceira partes, nas quais me detenho sobre as obras de Ana Luísa de Azevedo Castro e Maria Firmina dos Reis. Por fim, na última parte, são desenvolvidas algumas reflexões apontando para os modos pelos quais essas autoras desestabilizam algumas idéias já cristalizadas na historiografia e na crítica literária referentes às relações entre indianismo e identidade nacional.

É importante salientar que este trabalho não se pretende conclusivo; pelo contrário, é apenas o início de uma série de reflexões a serem feitas, pois a partir daqui fica clara a impossibilidade de continuar a pensar a "nação literária" como um monolito consolidado pelas "grandes obras do passado". O caminho percorrido não foi o de erigir um contra-cânone feminista, mas sim o de problematizar as representações presentes em obras celebrizadas, assim como o de questionar alguns dos parâmetros pelos quais certas obras são consideradas legítimas e relevantes, enquanto outras não o são. A partir do desvelamento de vozes silenciadas - como a voz das escritoras oitocentistas - fica clara a necessidade de redimensionar nossas concepções sobre a identidade nacional, levando também em consideração aqueles e aquelas que foram excluídos e só agora se fazem ouvir sem, no entanto, desconsiderar aqueles que já se tornaram consagrados.

\section{REVISITANDO O SÉCULO XIX A PARTIR DE UM OUTRO LUGAR}

No cenário atual da teoria e da crítica, são constantes comentários como "o sujeito está morto", "as ideologias fracassaram", ou ainda "a identidade está em crise". Stuart Hall faz um comentário muito pertinente em As Identidades Culturais na Pós-Modernidade, na medida em que esclarece controversos comentários que, muitas vezes, são lidos erroneamente:

Para aqueles/as teóricos/as que acreditam que as identidades modernas estão entrando em colapso, o argumento se desenvolve da seguinte forma. Um tipo diferente de mudança estrutural está transformando as sociedades modernas no final do século XX. Isso está fragmentando as paisagens culturais de classe, gênero, sexualidade, etnia, raça e nacionalidade, que, no passado, nos tinham fornecido sólidas localizações como indivíduos sociais. Estas transformações estão também mudando nossas identidades pessoais, abalando a idéia que temos de nós próprios como sujeitos integrados. Esta perda de um "sentido de si" estável é chamada, algumas vezes, de deslocamento ou descentração [sic] do sujeito. Esse duplo deslocamento descentração [sic] dos indivíduos tanto de seu lugar no mundo social e cultural quanto de si mesmos constitui uma "crise de identidade" para o indivíduo (HALL, 2000:9).

Em verdade, não é "o" sujeito ou "as" ideologias que estão mortos, falidos ou em crise, mas sim determinadas noções essencialistas atreladas a esses conceitos. Quando se fala em "morte do sujeito", o que se pretende pôr em relevo é a falência de um conceito essencialista, de uma definição totalizante de sujeito. A noção de sujeito passa a ser vista não como portadora de uma essência imanente, transcendental e imutável, mas sim como uma instância que está permanentemente sendo redefinida a partir de suas múltiplas relações com a realidade e o mundo exterior. Assim, não é o sujeito enquanto categoria analítica, mas sim uma das definições dessa categoria - a que o descreve como uno, autônomo e centrado - que está sendo questionada e problematizada na cultura ocidental patriarcal, a saber, branca e masculina.

No lugar deste sujeito uno e centrado que está sendo criticado, uma nova noção se instaura: a de um sujeito enquanto posicionalidade; não um sujeito fixo e atrelado ao seu correspondente empírico, mas sim um sujeito entendido como "em luta e em conflito para ocupar determinadas posições sociais na vida cotidiana" (QUEIROZ, 1997:126). Assim, o sujeito deixa de estar engessado pelo caráter metafísico, essencialista e transcendental de sua definição, ao mesmo tempo em que deixa de ser um mero efeito de linguagem (um risco que se corre, muitas vezes, com algumas definições pós-estruturalistas), para ser definido como uma posição assumida por um indivíduo historicamente marcado em relação ao seu próprio agenciamento frente a determinadas demandas políticas e identitárias. Ainda assim, não se pode negligenciar a importância da linguagem na configuração do sujeito, visto que toda a construção da subjetividade está por ela mediada.

Torna-se praticamente impossível pensar a categoria sujeito sem antes tocar nas questões em torno da ideologia e do discurso, categorias de extrema importância para compreender o descentramento do sujeito e a fragmentação das identidades culturais. Essas reflexões teóricas, por sua vez, se fazem pertinentes para o estudo de textos marginalizados, na medida em que os textos indianistas escritos por mulheres vão problematizar a construção de uma identidade nacional através do questionamento do pluribus unum, idéia que pauta o processo de fundação de uma identidade nacional. Tal como afirma Sérgio Prado Bellei em Nacionalismo e Literatura, "a procura e a gradual descoberta do nacional em literatura levam à constituição de um espaço hierarquizado que inclui o que vai se caracterizando como verdadeiramente nacional e exclui o que não chega a se caracterizar como tal" (1992:14). Assim, é através da operacionalização de categorias como discurso, ideologia, nacionalismo e identidade na leitura dos textos ficcionais de autoria feminina que se propõe a problematização das subjetividades representadas nos textos indianistas, dado que esses textos se configuram como narrativas a 
contrapelo, mostrando uma outra perspectiva, desautorizada, sobre a instauração da brasilidade dentro do projeto indianista.

Ideologia, tal como sujeito, é um conceito que vem sendo deveras questionado pelos diversos ramos das ciências sociais. Muitos, ao decretarem o fim das ideologias, decretam juntamente o fim da história, vista como a história da luta de classes. Pedro Lyra ${ }^{\text {iv }}$ (1992:152) afirma que essa é uma estratégia própria dos exploradores, que possuem interesses em eliminar a luta entre as classes, mas não as classes propriamente ditas. Afirma Lyra que "o que eles [os exploradores] querem impingir é apenas o fim da luta, preservando as classes, com a conseqüente resignação dos explorados" (idem, ibidem). Logo, torna-se possível perceber que o próprio ato de enunciação do fim da(s) ideologia(s) é, em si mesmo, um ato ideológico.

No momento em que foi forjada por Marx, a categoria ideologia foi confundida com a de ideologia dominante (ou hegemônica, tal como seria caracterizada mais tarde por Antonio Gramsci). Ao ser definida como o conjunto de concepções sociais e culturais de um grupo social específico, em um determinado momento da sua evolução histórica, a ideologia torna-se um conceito totalizante. Perde-se de vista o fato de que, em um determinado período histórico coexistem, com o conjunto de concepções relativo ao grupo dominante, diversos outros constructos de concepções culturais; estes últimos correm subterraneamente à vida social, paralelos à ideologia hegemônica, naturalizada como a única existente.

Destarte, fica evidente a existência de, ao menos, duas ideologias: a da classe dominante e a(s) da(s) classe(s) espoliada(s). Importante ressaltar aqui que todas essas reflexões são tecidas a partir de uma preocupação exclusivamente econômica: há uma classe que explora (burguesia) e outra que é explorada (proletariado). Entretanto, na medida em que esse conceito (ideologia) migra do campo das ciências políticas e econômicas para o da crítica literária e cultural, faz-se necessário repensar categorias como dominante e dominado, explorador e explorado. Sendo aqui o objeto de análise constituído por obras literárias, é importante percebê-lo não unicamente enquanto elaboração estética, mas antes, e principalmente, como produção, resultado do trabalho de forças produtivas, gerando valores que, por sua vez, passam a circular na forma de capital simbólico-cultural. A ideologia, aqui, funciona como o conjunto de valores e pressuposições que vem legitimar uma certa parcela da produção cultural, em detrimento de outras. Em outras palavras, o papel da ideologia é não apenas legitimar um determinado grupo social, mas legitimar como unicamente relevante e representativa a produção cultural e simbólica desse mesmo grupo:

A crítica marxista faz parte de um corpo mais amplo de análise teórica que tem por objetivo a compreensão das ideologias - as idéias, valores e sentimentos através dos quais os homens tomam consciência, em diversas épocas, da sociedade em que vivem. E algumas dessas idéias, valores e sentimentos só nos são acessíveis na literatura. Compreender as ideologias é compreender tanto o passado como o presente com mais profundidade [...] (EAGLETON, 1978:11).

Essa afirmação pode ser lida nos seguintes termos: compreender a ideologia subjacente à formação do período literário brasileiro conhecido como indianismo (a saber, um projeto de sedimentação e cristalização de uma identidade nacional una e monolítica) contribui para a apreensão dos interesses que levaram tanto a uma representação estereotipada do brasileiro autóctone quanto à exclusão das escritoras do mesmo período. A ideologia revela-se um conceito-chave para refletir de que forma categorias como raça e gênero são manipuladas por ocasião da fundação da identidade nacional através do atrelamento do discurso literário aos interesses de manutenção de uma raça e de um gênero como os legítimos dentro da criação literária da comunidade nacional brasileira:

Compreender a literatura significa, pois, compreender a totalidade do processo social de que ela faz parte. [...] As obras literárias não são fruto de uma inspiração misteriosa nem são explicáveis simplesmente em função da psicologia dos seus autores. São formas de percepção, maneiras determinadas de ver o mundo e, como tal, têm relações com a forma dominante de ver o mundo que é a "mentalidade social" ou ideologia de uma época. Essa ideologia é, por sua vez, produto das relações sociais concretas que os homens estabelecem entre si num tempo e lugar determinados; é o modo como essas relações de classe são sentidas, legitimadas e perpetuadas (idem:18).

Ao negar o estatuto da autoria às mulheres do século XIX, realiza-se um duplo movimento de exclusão e silenciamento no estabelecimento da categoria brasileiro: exclui-se as diferenças referentes às categorias identitárias de gênero e de raça. À mulher é negando o espaço de produtora de capital simbólico, enquanto ao índio é negada a possibilidade de outra modalidade de representação que não a do projeto indianista, cujo expoente maior é José de Alencar. Dadas as devidas proporções, mulheres e índios estavam submetidos a processos análogos de dominação: o patriarcalismo e o etnocentrismo. Ao pensar no romance indianista alencariano, as mulheres saltam a nossas vistas como importantes representantes do projeto de formação nacional: quem não se recorda das peripécias de Iracema, mãe do ilustre Moacir, o primeiro representante da raça cearence (e, por metonímia, da raça brasileira), ou da apaixonada Ceci, a civilizadora que retira o bon sauvage Peri de sua ignorância "natural" e o leva para os interstícios da cultura européia encravada no solo americano? Idem para os índios: a mesma Iracema salva o belo Martim e o guia pelas matas, ao passo que o bravo Peri salva sua amada do incêndio e do cruel Loredano. Ora, mais do que reivindicar espaço, o que aqui se pleiteia é uma análise que torne visível certos interesses políticos subjacentes à modulação do discurso no que tange à representação de raça e de gênero. Entenda-se aqui "político" na acepção dada por Eagleton, que afirma: 
Por "político" entendo apenas a maneira pela qual organizamos conjuntamente nossa vida social, e as relações de poder que isso implica [...] qualquer teoria relacionada com a significação, valor, linguagem, sentimento e experiência humanos, inevitavelmente envolverá mais amplas e profundas sobre a natureza do ser e da sociedade humanos, problemas de poder e sexualidade, interpretações da história passada, versões do presente e esperanças para o futuro (EAGLETON, 1983:209-10).

Gênero, pensado tanto como categoria de análise quanto como processo histórico e social, é relacional. É uma das noções de maior importância, tanto no momento em que se trabalha tanto com o resgate de textos de autoria feminina excluídos do cânone nacional quanto por ocasião da realização de uma reflexão crítica em torno desses textos. Ele tem a ver com a construção social de papéis relativos a uma subjetividade masculina e a uma subjetividade feminina, subjetividades estabelecidas em um campo de representação simbólica dos referidos papéis, tal como define Jane Flax ${ }^{\mathrm{v}}$ em artigo intitulado "Pós-Modernismo e Relações de Gênero na Teoria Feminista". Diz ela que:

As "relações de gênero" são uma categoria destinada a abranger um conjunto complexo de relações sociais, bem como a interferir a um conjunto mutante de processos sociais historicamente variáveis. O gênero, tanto como categoria analítica quanto como processo social, é relacional. Ou seja, as relações de gênero são processos complexos e instáveis [ou "totalidades" temporárias na linguagem da dialética] constituídos por e através de partes inter-relacionadas. Essas partes são interdependentes, ou seja, não têm significado ou existência sem as outras (FLAX. 1991:228).

Logo, as relações de gênero são o resultado de uma divisão social, estabelecida a partir de uma diferença sexual biológica. Via de regra, o gênero feminino figura, dentro da cultura patriarcal dominante, associado ao pólo natural, ao Outro e ao inconsciente, enquanto o gênero masculino é associado ao pólo cultural, ao Universal e à razão consciente. As acusações que muitas vezes são levantadas contra os estudos literários de gênero, bem como a uma série de estudos produzidos na esteira dos estudos feministas e culturais (em especial aqueles enunciados a partir da perspectiva de grupos étnicos ou sexuais marginalizados, como negros, índios, asiáticos e homossexuais) terminam mostrando-se produzidas em um locus enunciativo contaminado pela ilusão do gênero masculino enquanto "genericamente" universal. E aqui uso "genericamente" entre aspas para manter em suspenso a dupla significação do advérbio, pois até mesmo a noção de "genérico" já está, em sua matriz, contaminada pela diferença de gênero, pois parte do princípio de que o universal - o "sem gênero" - é declinado no masculino.

Algumas das críticas tecidas aos estudos culturais e de gênero acusam os mesmos de privilegiar "aspectos exteriores à obra", o que acaba se revelando um ponto de vista equivocado, visto que a investigação científica conta ainda com os estudos narratológicos (na esteira de nomes como Carlos Reis ${ }^{\mathrm{vi}}$, Mieke Bal ${ }^{\mathrm{vii}}$ e Gérard Genette $^{\text {viii }}$ ) como aparato fundamental para sustentar o trabalho de análise e teorização desenvolvido sobre a literatura de autoria feminina, levando em consideração elementos formais e estruturais do universo diegético. Em suma, é improcedente a afirmação de que os estudos culturais e literários de gênero deslizariam para um "sociologismo literário" e perderiam seu foco principal. Ao contrário, é através da articulação de diferentes saberes produzidos em diferentes áreas de conhecimento, como a narratologia, a teoria feminista e a psicanálise, entre outros, que se torna possível pensar a literatura de um outro lugar, questionando os saberes cristalizados pela historiografia literária oficialix .

Um outro ponto dentro dos estudos literários e que muitas vezes é "des-lido" é a questão da procedência da obra literária. Não é o simples fato de um texto ter sido escrito por uma mulher que o torna válido e/ou relevante para os estudos literários (sejam eles vinculados ou não aos estudos de gênero). Entretanto, freqüentemente esse argumento é invertido e deturpado, de forma a desqualificar textos de autoria feminina que, justamente através das peculiaridades da enunciação imbricadas na diegese narrativa, denunciam a dominação masculina dentro da sociedade. O silenciamento da participação de mulheres, negros e índios no processo de constituição identitária nacional é operacionalizado a partir de dois movimentos distintos: através da exclusão da participação desses grupos como produtores de representações culturais (deslegitimação de autoria negra, indígena e/ou feminina), e também pela construção de imagens estereotipadas desses sujeitos sociais no âmbito do capital simbólico produzido (a mulher passional, o índio travestido de cavalheiro romântico, o negro preguiçoso e indolente).

Homi Bhabha, ao investigar os processos de subjetivação que levaram ao nascimento do sujeito colonial $^{\mathrm{x}}$, levanta a questão do estereótipo enquanto elemento-chave para o funcionamento do discurso colonialista. "Isto porque é a força da ambivalência que dá ao estereótipo colonial sua validade: ele garante sua repetibilidade em conjunturas históricas e discursivas mutantes" (BHABHA, 1998:106-7). Ao construir discursivamente os sujeitos, a conjuntura colonial articula as diferenças (e penso aqui particularmente nas diferenças raciais) de modo a expurgá-las da esfera identitária legitimada. Assim, as representações culturais serão direcionadas de acordo com os interesses das elites socialmente hegemônicas, produzindo representações de gênero e raça que coloquem o outro em uma posição hierarquicamente inferior ao mesmo (ou ao "nós" colonial). O discurso colonial

[...] busca legitimação para suas estratégias através da produção de conhecimentos do colonizador e do colonizado que são estereotipados mas avaliados antiteticamente. O objetivo do discurso colonial é apresentar o colonizado como uma população de tipos degenerados com base na origem racial de modo a justificar a 
conquista e estabelecer sistemas de administração e instrução. [...] Portanto, apesar do "jogo" no sistema colonial que é crucial para seu exercício de poder, o discurso colonial produz o colonizado como uma realidade social que é ao mesmo tempo um "outro" e ainda assim inteiramente apreensível e visível (BHABHA, 1998:111).

O primeiro momento do Romantismo no Brasil, como se sabe, centrou seus esforços em produzir uma literatura genuinamente nacional. Ao mesmo tempo, foi o responsável por construir a nação brasileira enquanto uma "comunidade imaginada" (nas palavras de Benedict Anderson em Nação e Consciência Nacional), ou ainda enquanto um todo "coeso e monolítico" (de acordo com Said em Cultura e Imperialismo). Logo, a representação estereotipada do índio como naturalmente inferior, uma besta selvagem (ainda que mansa) necessitando de cultura e civilidade configura-se como uma necessidade para legitimar o "povo" brasileiro em processo de construção no âmbito das representações culturais. Ao índio foi delegado o papel de mero coadjuvante, uma espécie de representante do passado da nação, tal como o passado medieval foi eleito para o papel de antecedente cultural dos grandes Estados Nacionais europeus, também por ocasião do Romantismo.

Assim, em minha leitura dos romances indianistas de autoria feminina, analiso de que forma o pertencimento social diferenciado das escritoras vai ser refletido e refratado em sua produção de artefatos culturais. Dado o fato das mulheres estarem à margem enquanto produtoras de representações simbólicoculturais, a percepção destas em relação ao papel do índio (e das próprias mulheres) dentro do script narrativo indianista seria diferenciada? É isso o que será averiguado a partir de agora.

\section{A METÁFORA NACIONALISTA: D. NARCISA DE VILLAR, DE ANA LUÍSA DE AZEVEDO CASTRO}

O romance D. Narcisa de Villar: legenda do tempo colonial pela Indígena do Ipiranga, de Ana Luísa de Azevedo Castro, está entre os primeiros romances de autoria feminina publicados no Brasil. É relevante lembrar que, no mesmo ano de sua publicação (1859), foi publicado também o romance Úrsula, da escritora maranhense Maria Firmina dos Reis. Como tipicamente acontecia àquela época, o romance D. Narcisa de Villar circulou anteriormente à sua publicação em livro, na forma de folhetim, no jornal fluminense $A$ Marmota, durante o período de 13 de abril a 6 de julho de $1858^{\mathrm{xi}}$.

Não se sabe muito sobre a vida dessa escritora. O pouco que se conhece de sua obra deve-se ao trabalho de J. Galante de Sousa ${ }^{\text {xii }}$ e Zahidé Muzart ${ }^{\text {xiii }}$. Uma biografia mais completa somente seria possível a partir de pesquisas mais aprofundadas no Rio de Janeiro, cidade na qual Ana Luísa de Azevedo Castro passou a maior parte de sua vida. Mesmo a sua data de nascimento não é dada como certa. Muzart (2000:250) aponta o ano de 1823, e o local mais provável seria a cidade de São Francisco do Sul, no Estado de Santa Catarina. Além de professora, Castro foi também membro da Sociedade Ensaios Literários, a qual, em 16 de abril de 1866, lhe conferiu o diploma de sócia honorária. Faleceu no Rio de Janeiro, em 22 de Janeiro de 1869, com cerca de 46 anos.

Antecedendo a narrativa romanesca propriamente dita, há uma espécie de prólogo intitulado "Ao Público". Assim como em vários outros romances brasileiros escritos por mulheres no século XIX, a escritora vem, através desse "prólogo" anterior à narrativa, "rogar a benevolência daqueles que me lerem" (Castro 1990:9). Da mesma maneira como o faz Maria Firmina dos Reis em sua obra Úrsula, a autora de D. Narcisa de Villar traz, antecipando seu texto ficcional, um pedido de desculpas pelo pecado que está cometendo: o de, em um universo de homens, ousar a escrever, ainda que sendo mulher. Esse tipo de "prefácio" - tão típico tanto em termos de forma quanto em termos de conteúdo nos romances escritos por mulheres no século XIX - mostra que não apenas Castro e dos Reis, mas muitas outras escritoras da época, manifestavam consciência das condições sociais às quais as mulheres escritoras oitocentistas estavam submetidas no Brasil: a de não-reconhecimento do status autoral dos seus escritos, não legitimando, desta maneira, a incorporação de tais obras no elenco de representações e valores sócio-culturais constitutivos do imaginário simbólico nacional.

O enredo de D. Narcisa de Villar, se observado de uma forma pouco atenta, soa como tipicamente indianista: trata do embate colonial entre duas civilizações distintas: a portuguesa colonizadora, de um lado, e a indígena autóctone brasileira, de outro. Entretanto, o desenvolvimento dos fatos se dá de forma diferenciada, se comparado ao típico script narrativo dos romances alencarianos. A narrativa de Castro desenvolve-se da seguinte forma: D. Narcisa, ainda criança e em Portugal, perde os pais e se vê obrigada a deixar as terras lusitanas e viajar para o Brasil, com vistas a viver com os seus irmãos. Logo no primeiro capítulo, há uma passagem na qual a narradora descreve o caráter despótico já referido dos irmãos de D. Narcisa:

Estes governadores [os irmãos de Narcisa], usando quase sempre de um poder despótico, os únicos sentimentos que despertavam nesses espíritos tão impressionáveis que podiam fazer voltarem-se facilmente ao bem, eram os da aversão e vingança. A iníqua opressão e torpe injustiça que quase geralmente era exercida contra essa pobre gente, cimentavam com incremento fatal esse ódio terrível, cujo amargor devia legar em herança a suas futuras gerações, esse povo então na infância dos costumes (CASTRO, 1990: 23-4).

Tendo em mente que esse trecho se detém na descrição dos irmãos de Narcisa (D. Martim, D. Luís e D. José de Villar), nota-se de imediato que a voz narrativa se mostra acumpliciada com a visão marginal, não se 
subordinando ao signo colonial português; ao contrário, se coloca desde o início da narrativa contra tal signo. Passada a infância de D. Narcisa, continua ela sob a guarda dos irmãos, que se mantêm emocionalmente distantes; as únicas pessoas que estão realmente próximas de D. Narcisa são a velha Efigênia e Leonardo, filho da primeira. Efigênia é uma espécie de "empregada" da família de Villar, e Leonardo é o seu único filho. Leonardo e Narcisa crescem praticamente juntos, como irmãos, e a jovem beldade portuguesa vive sua infância entre brincadeiras e lições religiosas com o mancebo Leonardo. Em um dado momento, entretanto, D. Narcisa bruscamente se depara com a realidade: a de que sua infância terminou. É neste momento que os irmãos de D. Narcisa comunicam-lhe sua decisão: a de que ela deve se casar com o coronel Pedro Paulo, rico fidalgo português. É exatamente nessa ocasião que desperta a já latente paixão entre Narcisa e Leonardo. Declaram simultaneamente seu amor e decidem não se subordinar à decisão dos irmãos D. Martim, D. Luís e D. José de Villar. No momento da cerimônia de casamento, Leonardo seqüestra Narcisa e, em uma canoa, ambos fogem para a Ilha do Mel. Abrigados em uma gruta na ilha, são encontrados e assassinados pelos perseguidores. Antes da morte de Leonardo e Narcisa, Efigênia revela a todos que Leonardo é filho de D. Luís, um dos irmãos de D. Narcisa. Portanto, antes da morte, o idílio é mostrado como incestuoso, visto que Leonardo e Narcisa têm o mesmo sangue, complicando ainda mais o problemático idílio.

Ana Luísa de Azevedo Castro, rompendo com a suposta neutralidade do narrador romanesco, desloca o locus de enunciação da voz narrativa. Ao filiar a instância enunciativa marcada pela diferença, recuperando aquilo que foi apagado e que Bhabha identifica como "o sinal de menos na origem" (justificando a emergência de suplementos que vão dar conta dessa subtração), obtém-se um resultado que, contrariando a lógica matemática, não apenas "acrescenta", mas sim altera completamente o cálculo: "[a] estratégia suplementar interrompe a serialidade discursiva da narrativa de plurais e do pluralismo ao mudar radicalmente o seu modo de articulação" (BHABHA, 1998:219). Assim, ao recuperar a perspectiva dos índios e mulheres dentro da narrativa indianista, Castro denuncia a violência do processo colonial, pois a voz narrativa está inscrita no gênero pelo pertencimento (a narradora de D. Narcisa de Villar é Taim, uma mulher, o que já declina a instância de enunciação no feminino) e pela afiliação solidária ao índio. Deslocando a perspectiva narrativa, Castro recupera aquilo que foi subtraído no início (as diferenças de raça e de gênero apagadas no processo de elaboração do capital simbólico), possibilitando a emergência de suplementos, de acordo com o raciocínio de Bhabha. Esta afiliação é tornada explícita no prólogo do romance e, como resultado, a narradora expõe a violência do processo colonial no âmbito da enunciação narrativa:

O vício praticado por tantos fascinorosos saídos das cadeias de Lisboa, que vinham povoar as colônias, progredia com mais força, suplantando toda a sombra de civilização que não podia medrar sem religião. Por isso vemos até hoje muitas de nossas vilas e cidades tão antigas na história e tão retrógradas no engrandecimento.

D. Martim de Villar era um dos tiranos mandados ao Brasil em quem recaíra a má escolha do governo português (CASTRO, 1990:23-4).

Ao mostrar uma nova perspectiva sobre o embate entre o colonizador português e os americanos autóctones, a escritora derruba a possibilidade de construção de um brasileiro legítimo através da miscigenação entre o idealizado bon-sauvage brasileiro e a brancura aristocrática dos brancos europeus. No lugar de um idílio que terminaria com o nascimento de um representante mestiço (como em Iracema, o segundo romance da trilogia indianista de Alencar, no qual Moacir perde todas as marcas de pertencimento à raça da mãe, e herda o legado branco e falocêntrico do pai), Castro desconstrói e subverte o mito do idílio indianista, dando um desfecho trágico ao amor de Leonardo e D. Narcisa.

Em outro romance alencariano, $O$ Guarani $^{\text {xiv }}$ (1857), há um par idílico que lembra um pouco os protagonistas de D. Narcisa de Villar: uma relação amorosa estabelecida entre um homem índio e uma mulher branca (ao contrário de Iracema, romance no qual o par idílico é formado por um homem branco e uma mulher indígena). Entretanto, o desenrolar do enredo alencariano em $O$ Guarani é completamente complacente com o ideal preconizado pelo script narrativo indianista: dada a impossibilidade da relação entre uma branca (por ser mulher em uma sociedade na qual o sujeito de direito é, por excelência, o homem) e um índio (raça inferior, premiada com a camaradagem dos brancos quando é um "índio bom", e com a morte quando contraria ou questiona o status quo da elite hegemônica), a solução que Alencar encontra para $O$ Guarani é uma união que culmina não com a consumação do amor, mas sim com uma morte simbólica e purgatória, na medida em que representa o indígena como um selvagem que aceitou a salvação cristã (leia-se: aculturação) e a mulher como uma dama virtuosa, um sujeito não-desejante que preserva sua castidade até o momento em que isso (supostamente) se torna impossível: o momento da morte na cachoeira. Ainda que se possa deduzir uma possível união amorosa - no caso de se tomar a cachoeira como uma metáfora para a união erótico-afetiva de Peri e Ceci é somente em Iracema que Alencar vai efetivamente metaforizar a raça cearense - representando a identidade nacional brasileira - como o resultado da união da raça branca (portadora da cultura colonial) com a raça indígena - o índio "medievalizado" e transformado em cavalheiro cortês - ou, no caso de Iracema, em dama a ser amada e possuída, mero objeto a ser apreciado pelo sujeito desejante masculino.

Heloísa Toller Gomes ${ }^{\mathrm{xv}}$, em "A Questão da Nacionalidade: Relações Raciais e Código Erótico na Literatura Brasileira Oitocentista" registra que, via de regra, em praticamente toda a produção literária do século 
XIX, a relação que se estabelece entre indivíduos de diferentes raças (mulher branca e homem indígena) resulta em um casamento infecundo, sem filhos, enquanto a união entre homem branco e mulher índia resulta em um filho que herda do pai o poder patriarcal, garantindo a manutenção do quadro de dominação colonial (como em Iracema). Afirma ela que:

Tampouco se alude a um livre trânsito entre os sexos. São raros os exemplos de envolvimento sexual entre mulher branca e homem não-branco. A quase exclusividade é sintomática: a posse da mulher não-branca pelo branco metaforiza o quadro da conquista e o re-asseguramento da ordem patriarcal. Já a direção oposta significaria subverter essa mesma ordem. O discurso literário, assim, bloqueia aquilo que, embora sucedendo na realidade, infringia grave norma social. É esta norma social que o corpus literário expõe, em seu existir metafórico (1995:390).

Ao contrário da relação que se desenvolve entre Martim e Iracema, o romance de Castro traz um amor que não se concretiza, no qual a união se dá alguns minutos antes da morte, apontando para um final trágico. $\mathrm{O}$ idílio de D. Narcisa e Leonardo não é compatível com o projeto nacional etnocêntrico dos "bravos colonizadores portugueses". Isso porque, dentro do ideário colonial, a genealogia era terminantemente patrilinear; a consumação do amor entre um índio e uma branca não tinha legitimidade dentro do processo romântico de constituição nacional porque não gerava uma descendência ligada ao colonizador. Embora a mulher branca não esteja excluída de tal processo, sua participação - tal como ocorre em $O$ Guarani - restringe-se à instância reprodutiva.

Essa incompatibilidade entre o idílio consumado e o processo de constituição nacional está marcada pela origem dos enamorados. Leonardo, assim como o próprio Moacir alencariano, é um híbrido descentrado, filho de Efigênia e D. Luís, um dos irmãos de D. Narcisa. Essa, sendo mulher, é também despoticamente colonizada e silenciada. Mesmo sendo ela uma portuguesa, portanto, pertencente à esfera do colonizador europeu, a condição feminina a torna subordinada aos desígnios dos irmãos. Enquanto Iracema traz essencialmente a romanticização do idílio, D. Narcisa de Villar traz uma narrativa na qual o violento drama do encontro amoroso entre as duas raças é levado ao extremo. Em Castro o idílio não é a origem da "raça" cearence (que pode, por metonímia, ser vista como a "raça" brasileira), tal como pode ser visto em Alencar (e penso aqui no romance Iracema), mas sim a metáfora par excellence para denunciar a ideologia do discurso colonial, e sua respectiva violência, tanto simbólica quanto concreta. Assim, afirma-se o caráter trágico ${ }^{x v i}$ de Castro, em contraste com o caráter idealista da narrativa de Alencar.

Ao inverter o binômio idílico índia/colonizador alencariano (representado por Iracema e Martim), e deslocá-lo colocando uma branca expatriada e um Leonardo mestiço (um “irmão”, por assim dizer, de Moacir, resultado da profanação da mulher autóctone pelo colonizador português), a autora mostra que, na verdade, a participação da mulher branca no processo de construção mítica da raça brasileira está limitada ao fornecimento de herdeiros legítimos para o opressor português, enquanto os "frutos" do sofrimento das iracemas americanas estão condenados a servirem a seus pais-senhores, como índios um pouco mais "civilizados", batizados e colonizados, como é posto por Alencar ao final de Iracema:

Muitos guerreiros de sua raça [da raça de Poti] acompanharam o chefe branco [Martim], para fundar com ele a mairi dos cristãos. Veio também um sacerdote de sua religião, de negras vestes, para plantar a cruz na terra selvagem.

Poti foi o primeiro que ajoelhou aos pés do sagrado lenho; não sofria ele que nada mais o separasse de seu irmão branco. Deviam ter ambos um só deus, como tinham um só coração.

Ele recebeu com o batismo o nome do santo, cujo era o dia; e o do rei, a quem ia servir, e sobre os dois o seu, na língua dos irmãos [...] (ALENCAR, [s.d.]:96) [ grifos meus].

Através de um discurso que constrói o índio como besta a ser civilizada e a mulher como apenas um ventre fértil ou fonte extra de custos, vê-se que não apenas o espaço físico nacional foi colonizado, mas também a subjetividade do índio e da mulher. Mesmo o nome de origem de Poti é traduzido, de forma a romper com todos os vínculos do índio com sua antiga raça.

O romance traz também um "Prólogo" no qual a narradora deixa claro não ser ela quem primeiro relatou a história que será contada no decorrer da narrativa. A primeira dessas narradoras é Mãe Micaela, a velha índia, que conta a história de D. Narcisa a Taim ${ }^{\text {xvii }}$, ao ser questionada sobre o motivo pelo qual a Ilha do Mel é considerada assombrada. A segunda narradora é a própria Taim, a narradora "culta", que fixa o relato feito oralmente por Mãe Micaela. Importante ainda ressaltar que o relato de Mãe Micaela é feito à volta da fogueira, espaço onde a tradição oral é transmitida às novas gerações:

[...] ao pé de um bom fogo, cujo calor saboreávamos com delícias, pelo frio que fazia, e onde se assavam carás e batatas roxas, que eu [Taim] comia com delicioso prazer, eu ouvia também as histórias que me contavam duas Índias velhas, com seu falar pausado e cadencioso, com essa algaravia única, em que se misturam as línguas primitiva e a portuguesa adotada, que tanto me agradava (CASTRO, 1990:20).

Há uma cumplicidade da narradora branca (Taim) com Mãe Micaela. Essa se configura como a narradora "original e empírica" da narrativa. É a voz subjacente ao discurso de Taim, a narradora branca que vai, através da escrita, legitimar a perspectiva indígena sobre o advento da colonização. Mesmo sendo branca, Taim incorpora o discurso do índio ao seu próprio discurso, dando visibilidade ao mesmo. É o que se passa neste outro trecho: "[Mãe Micaela] começou a contar sua história do modo por que a vamos expor (...) perdoe-nos o leitor 
que a substituamos pela nossa linguagem, guardando todavia certas expressões que pertencem inteiramente à narradora [oral]" (Castro 1990:20). Destarte, a construção do nível da enunciação (caracterizada pela instauração de uma voz narrativa, responsável por contar uma história) mostra-se caracterizado pelo lugar de origem dessa voz, que é o de um narrador declinado no feminino, participante de uma cultura letrada e pertencente à raça branca (Taim). Essa presença feminina, letrada e branca legitima a voz do índio através de uma afiliação empática que, em nenhum momento, reduz as narradoras orais (Mãe Micaela e Simoa, índias que não dominam a cultura letrada) à condição de objeto representado em seu discurso. Assim, ao contrário do narrador alencariano, que deixa clara as suas filiações de raça (branca) e gênero (masculino), e se põe em um lugar hierarquicamente superior à etnia indígena presente em $O$ Guarani e em Iracema, Taim coloca-se em uma relação horizontal, na qual a diferença não é tida como um dado valorativo. O olhar de Taim não está sobre o objeto, mas ao lado dele, o que redimensiona a perspectiva do idílio romântico enquanto metáfora da identidade erguida pelo projeto indianista.

A representação da natureza no romance de Castro é um outro dado importante, que diz muito sobre a perspectiva adotada para narrar o processo romântico de construção da brasilidade. Para fazer o contraponto com D. Narcisa de Villar, tome-se novamente o Iracema:

A tempestade cada vez ia mais se avizinhando com terríveis ameaças; agudos sons do trovão se ouviram como um gemido medonho no infinito, como um pavoroso aceno do furacão prestes a desabar.

A donzela estremeceu e chegou-se mais perto do seu amigo, o qual ainda com mais força remou. De repente um relâmpago abriu as nuvens mesmo sobre suas cabeças, e um raio veio cair não longe da canoa; foi o sinal para a tempestade cair com furor (CASTRO, 1990:65).

O galo da campina ergue a poupa escarlate fora do ninho. Seu límpido trinado anuncia a aproximação do dia.

Ainda a sombra cobre a terra. Já o povo selvagem colhe as redes na grande taba e caminha para o banho. O velho pajé que velou toda a noite, falando às estrelas, conjurando os maus espíritos das trevas, entra furtivamente na cabana (ALENCAR, [s.d.]:22).

Alencar usa os trechos descritivos, nos quais retrata as paisagens selvagens, para exaltar a nação através de sua exuberante natureza (a questão da cor local). A mestiçagem (ou melhor, o branqueamento do índio) é uma necessidade para que se possa asseverar uma origem para o povo brasileiro. A marcação de uma matriz autóctone e selvagem não legitima apenas a raça brasileira, mas também a função do colonizador português, que é a de "civilizar" o índio. A descrição da natureza em Alencar não apenas marca a barbárie na qual estão imersos os índios, mas também enobrece o caráter soberano da nação brasileira através da vitória do homem branco sobre o espaço "selvagem", em um momento essencial para a construção da identidade da nação brasileira.

D. Narcisa de Villar, diferentemente de Iracema, traz uma representação da natureza que não tem nada do ideal edênico do qual nos fala Sergio Buarque de Holanda em Visão do Paraíso ${ }^{\text {xviii }}$. Ela não está lá simplesmente para legitimar um projeto nacional identitário através do espaço narrativo, nem para legitimar o processo civilizatório branco. A natureza descrita por Castro é a natureza dionisíaca, noturna, uma instância que se opõe aos protagonistas do idílio, mostrando-se não como provedora amistosa, mas como espaço trágico, marcado pela crueza das descrições, como pode ser visto no momento em que a narradora descreve a gruta onde Leonardo e D. Narcisa se escondem dos perseguidores:

O teto era um grosso rochedo que parecia tão estável e seguro, que não se abalaria mesmo com as águas do dilúvio. Quando o mar enchia demasiado, lavava todo o interior, e o limo que ali deixava alimentava esse musgo sempre verde, que tapisando esse belo pavimento, encantava como um felpudo tapete à vista do observador. Os pássaros aquáticos escolhiam essa caverna para abrigar sua tenra prole [...] (CASTRO, 1990:69) [ grifo meu].

Mesmo no momento em que a narradora descreve o refúgio dos enamorados, faz questão de marcar o caráter violento e ctônico da natureza. A gruta, espaço de refúgio utilizado tanto pelos amantes em fuga quanto pelas aves aquáticas, é periodicamente invadido pelas violentas ondas do mar. Porém, ao contrário dos pássaros que sofrem apenas com a ameaça marinha, Leonardo e D. Narcisa sofrem com a opressão humana: aquilo que aparentemente é um refúgio seguro se torna, na cena final do romance, o altar sacrificial dos enamorados pelos irmãos de Narcisa. Os pássaros são utilizados por Castro para marcar não a beleza oculta da selva, mas sim os prenúncios de mau agouro. Alencar, pelo contrário, utiliza a figura dos pássaros para colocar um colorido no quadro selvagem. "O galo da campina ergue a pompa escarlate fora do ninho. Seu límpido trinado anuncia a aproximação do dia” (ALENCAR, [s.d.]:22).

A representação da natureza com tons violentos, tal como é feita por Castro, repete-se em Gupeva, de Maria Firmina dos Reis. Tal estratégia está intimamente relacionada com o desfecho trágico dessas duas narrativas que, ao contrário dos romances alencarianos, mostram o contato entre a cultura autóctone e a cultura européia não como um encontro amistoso e pacífico, mas sim como um embate marcado pela violência colonial. Castro e dos Reis mostram, através das representações do índio e da mulher que ambos foram vitimados pelos interesses coloniais: mesmo a mulher branca (em D. Narcisa de Villar) está submetida ao despotismo dos portugueses. $\mathrm{O}$ embate entre a instância do colonizador e a instância dos corpos colonizados é representado dramaticamente em um cenário inóspito e pouco amistoso; já em Iracema há o espetáculo romântico fundacional sobre um cenário que tem a função de legitimar o processo da própria fundação de uma identidade nacional. Fazse, necessário, pois, antes de aprofundar a investigação sobre o funcionamento do discurso e da ideologia 
colonial dentro desses romances, uma aproximação mais detalhada sobre a obra de Maria Firmina dos Reis.

\section{VIOLÊNCIA E INTERTEXTO: GUPEVA, DE MARIA FIRMINA DOS REIS E SUAS INTERFACES COM AS NARRATIVAS DE CASTRO E ALENCAR}

Diferentemente do que aconteceu com Ana Luísa de Azevedo Castro, boa parte do percurso da vida de Maria Firmina dos Reis pôde ser levantado por alguns pesquisadores que se detiveram sobre sua singular atuação nas letras e na educação. Em 11 de outubro de 1825, nasce a escritora e professora Maria Firmina, mulata e bastarda, filha de João Pedro Esteves e Leonor Felipe dos Reis, na Ilha de São Luís, Maranhão. Em 1847, foi aprovada no concurso de Instrução Primária no município de Viamão, e ali exerceu a profissão, como alfabetizadora, de 1847 a 1881 . Em 1859 publicou o romance Úrsula, primeiro romance abolicionista da literatura brasileira, e um dos primeiros de autoria feminina a ser publicado no Brasil. Desde então, publicou, nos mais diversos gêneros, em vários jornais literários ${ }^{\mathrm{xix}}$. Entre outras narrativas de sua autoria, há o registro do conto "A Escrava", de 1887. Publicou várias poesias esparsas em jornais e, em 1871, publicou um livro de poesias intitulado Cantos à Beira-Mar (reproduzido em fac-símile por José Nascimento Moraes Filho em $1975^{\mathrm{xx}}$.

Maria Firmina dos Reis não se destacou apenas pela sua produção literária e musical (há pelo menos cinco composições suas das quais se tem registro ${ }^{\mathrm{xxi}}$ ), mas também por sua atuação social como educadora. Em 1880, fundou uma escola gratuita mista, o que causou escândalo na época, obrigando-a a fechar seu estabelecimento dois anos e meio depois de sua abertura. Zahidé Muzart escreve:

$\mathrm{O}$ fato de ter fundado a primeira escola mista do país mostra as idéias avançadas de Maria Firmina para a época. Pense-se no tipo de educação que recebiam as meninas no século XIX: leitura, com o objetivo religioso, bordado, piano e para algumas o ensino do francês, língua da sociedade! (MUZART, 2000:265).

Boa parte do conhecimento que temos sobre a vida e sobre a obra de Maria Firmina dos Reis é fruto do trabalho do pesquisador José Nascimento Moraes Filho, que em 1975 reuniu os escritos dispersos da escritora maranhense, entre eles o conto "A Escrava", diversos poemas, algumas opiniões críticas e o folhetim Gupeva: romance brasiliense. $\mathrm{O}$ abolicionismo é praticamente um leitmotiv na produção dessa escritora. Entretanto, Gupeva destaca-se muito mais pelo diálogo estabelecido com a tradição indianista brasileira do que pelo acento abolicionista, este romance apresenta um complexo e imbricado enredo, com várias referências a representações de indígenas na tradição literária brasileira: o próprio nome Gupeva tem como origem o poema Caramuru, de Santa Rita Durão.

Ainda que Zahidé Muzart tenha realizado um trabalho de inegável monta, questiono aqui a validade de algumas das afirmações que esta realiza no verbete que dedica a Maria Firmina dos Reis em Escritoras Brasileiras do Século XIXXxii. À página 267 da referida antologia, Muzart afirma: "Gupeva é o tipo de narrativa desastrada tais os erros de enredo que apresenta". Mais adiante, Muzart faz o seguinte comentário, por ocasião do enredo de Gupeva:

Complicações de folhetim. Até o resumir se torna complicado! De quebra, também aparece, em rápido close, a índia Paraguaçu! Um romance esquecido e que, parece-me, assim ficará (MUZART, 2000:268).

Por fim, ao comentar o conto "A Escrava", Zahidé Muzart tece o seguinte julgamento: "mais bem construído que Gupeva, [o conto "A Escrava"] ainda assim não apresenta o mesmo interesse do romance Úrsula, de longe a melhor narrativa escrita por Maria Firmina" (id. ibid.) Ainda que, em um primeiro momento, possa parecer que a pesquisadora tenha inventariado em grau de importância uma espécie de "hierarquia" das narrativas da escritora maranhense (sendo que, dentro dos critérios utilizados, Úrsula seria a narrativa melhor acabada, "A Escrava" um conto com alguns problemas e Gupeva "um romance esquecido, e que assim ficará"), torna-se visível um problema freqüentemente presente dentro das pesquisas de resgate envolvendo os escritos de mulheres do século XIX: a questão do valor literário. Ainda que não seja o foco principal da análise do romance Gupeva, a questão do valor literário ou da qualidade estética será retomada por ocasião das considerações finais. Uma afirmação valorativa como esta não estaria reproduzindo o mesmo discurso exclusionista que manteve as 52 escritoras resgatadas pela antologia no silêncio e no esquecimento?

Gupeva: romance brasiliense, veio a público pela primeira vez no jornal $O$ Jardim dos Maranhenses entre 1961 e 1962. Em 1963, o folhetim de Maria Firmina dos Reis é republicado duas vezes: uma no jornal Porto Livre, outra no jornal Ecos da Juventude. Depois disso, somente veio a ser reeditado a partir da transcrição (integral) que José Nascimento Moraes Filho fez dele em seu Maria Firmina: fragmentos de uma vida, em 1975. Gupeva é uma narrativa dividida em cinco capítulos. Partindo da informação de que foi publicado pela primeira vez em folhetim, pode-se supor que essas cinco partes são relativas a cinco números distintos de $O$ Jardim dos Maranhenses, dado que - via de regra - a divisão em capítulos de romances inicialmente publicados em folhetim obedecia a este critério. Se tal hipótese for verdadeira, fica uma dúvida em suspenso: por que a narrativa de Maria Firmina dos Reis se estendeu apenas por cinco números do jornal? Pense-se, por exemplo, nos longos períodos que os folhetins de Alencar e outros escritores românticos levavam para ser concluídos. Sendo assim, torna-se possível levantar duas hipóteses: ou a obra não foi bem recebida pelo público, ou a escritora foi 
impedida de estender sua narrativa, sendo obrigada a finalizá-la antes do momento em que havia previsto. Dado que, no ano seguinte ao final de sua primeira publicação, dois outros jornais (Porto Livre e Eco da Juventude) republicaram a narrativa, penso que a segunda hipótese seja verdadeira. Entretanto, tal questão demanda uma investigação mais aprofundada, que abarcasse, por exemplo, o cotejo dessas três versões nos jornais de época, o que, por razões de indisponibilidade de material, impossibilita uma especulação mais profunda no presente estudo.

A narrativa inicia-se com o jovem Gastão apoiado em seu navio, portando um olhar triste que desperta o interesse de um outro jovem oficial, chamado Alberto. A ênfase da narração recai sobre o semblante de Gastão, que deixa transparecer saudade e melancolia:

Seus olhos ardentes pareciam querer divisar através dessas matas ainda quase virgens um objeto qualquer. Sem dúvida nesse lugar outrora solitário, hoje populoso e civilizado, havia alguma coisa que o mancebo amava mais que a vida, em que fazia consistir a toda sua felicidade, resumia todo o seu querer, todas as suas ambições, toda a sua ventura (DOS REIS, 1975:105).

A partir do diálogo travado entre os oficiais Gastão e Alberto emerge o cerne da narrativa: o amor entre o jovem francês (Gastão) e uma brasileira (a jovem índia de nome Épica). O jovem Gastão encontra-se à beira da loucura, pois chega mesmo a pôr em risco as possibilidades de ascensão na carreira militar em prol dos sentimentos que cultiva pela jovem indígena brasiliense. Ainda nesse diálogo, os dois personagens são pintados com cores nacionais: o temperamento de Gastão, impetuoso e apaixonado, é associado à sua origem francesa, enquanto o ponderado e racional Alberto se coloca como um representante do típico pensamento português. O fato de Gastão ser um francês em uma embarcação portuguesa pode ser interpretado como uma saída encontrada por Maria Firmina dos Reis para desassociar o representante masculino do "romance-fundador" do nacionalismo que marca os portugueses enquanto colonizadores:

- Alberto, tu não és francês, o teu clima cria almas intrépidas, corações fortes ou rudes, ardendo sempre mas em fogo belicoso: o sangue que herdaste de teus avós gira em teu peito como ambição de glória, de renome; são nobres as tuas ambições, eu as respeito; porém as minhas são destituídas de toda a vaidade (...)

- Todos nós, lhe disse Alberto, temos a nossa hora de loucura; também o português, meu caro, a experimenta às vezes, não obstante como dizes, o nosso clima gera corações mais rudes; mas, Gastão, teus pais! Queres acaso afrontar a maldição paterna? (DOS REIS, 1975:07).

Gastão solicita então, ao final de sua conversa com Alberto, que este tome seu lugar, visto que o jovem francês deveria entrar de quarto (qualquer coisa como fazer a guarda da embarcação) durante à noite, pois Gastão havia marcado um encontro em terra com Épica. Alberto concorda com a substituição tendo em vista sua grande estima por Gastão. A fala de Alberto, ao aceitar a substituição de posto, marca o que poderia ser chamado de um momento divisor de águas na narrativa:

- Compreendo-te! Gastão, o teu delírio, meu caro, te faz ingrato. És surdo a minha voz sensível aos extremos da amizade... Vai, Gastão, vê essa mulher que te fascinou, como fascinam as cobras de seu país a míseros pássaros. Tu também és um pássaro, nascido em regiões estranhas, que levantaste o teu vôo, atravessaste os mares, e posaste amoroso nas franças do pau d'arco americano; Gastão, não te deixes atrair da serpente venenosa; goza um momento disso, a que chamas a tua felicidade; mas desprende novamente o vôo (idem:108).

Em sua fala, Alberto prenuncia perigos obscuros através de metáforas, tais como a associação de Épica com as cobras que fascinam os pássaros para depois devorá-los, e de Gastão com os pássaros hipnotizados por tais cobras ("tu também és um pássaro, nascido em regiões estranhas"). A partir dessa fala, a voz narrativa não mais pintará o cenário com as cores alegres, salientando os aspectos paradisíacos do Brasil ${ }^{\text {xiii. }}$; ao contrário, a natureza será apresentada a partir desse ponto como o cenário funesto e ameaçador, prenunciando perigos e desgraças, tal como o espaço narrativo criado por Castro em D. Narcisa de Villar.

Em terra finalmente, o jovem Gastão vai ao encontro de sua amada, Épica, em mata fechada. A noite cai e a atmosfera começa a dar mostras de que uma tempestade se aproxima. "Havia um negrume espantoso, porém a natureza ainda estava calma; a tempestade que ameaçava não prometia ser breve" (DOS REIS, 1975:110). A tempestade, que também está presente na narrativa de Castro, é como um verniz que embota a paisagem: esta deixa de ser um espaço paradisíaco, para dar lugar, sob os auspícios da tempestade, ao palco trágico do desfecho idílico. Finalmente o jovem francês chega a um bosque solitário e ermo onde aguardava sua amada. Tenso, Gastão aguarda e, enquanto aguarda, entrega-se à meditação. Refletindo sobre o amor e a morte chega à conclusão de que

[...]do mundo só almejava uma coisa, uma somente, do mundo ele só queria aquela mulher, que ele aguardava com frenesi, aquela mulher, que ela aguardava com delírio, que idolatrava loucamente. Por ela Gastão daria toda a sua vida, todo o seu sangue, sua alma, seu sossego, toda a felicidade de um futuro, que se lhe antolhava risonho (DOS REIS, 1975:111).

Em meio aos seus pensamentos, Gastão é assaltado por um ruído da mata que o desperta novamente para o mundo. Surpreso e assustado, frente a frente com um homem desconhecido, Gastão ouve a pergunta: "- quem sois?" (idem, ibidem). Tentando identificar o vulto, Gastão repete a pergunta, e ouve como resposta "eu sou tupinambá (...), sou o cacique desta tribo, sou finalmente o pai de Épica. Isto espanta-vos?” (idem, ibidem) Desembainhando sua espada, Gastão arremessa-se contra o cacique. Ao ouvir as seguintes palavras, entretanto, o 
jovem francês domina seus ímpetos e ouve o cacique:

- Esperai, mancebo, esperai, lhe disse o índio, juro-vos por Tupã que hei de matar-vos ou morrer às vossas mãos, e isto antes do meio giro da lua; porque a essa hora Épica, a inocente Épica, virá louca, correndo ao vosso encontro, e só um de nós a deve receber. Se fordes vós ao menos eu não testemunharei semelhante aviltamento (DOS REIS, 1975:112).

O velho começa então, sua narrativa. Há muitos anos, no mesmo bosque no qual agora se encontravam o cacique tubinambá e o jovem francês, um velho cacique, acompanhado de um jovem índio chamado Gupeva, despedia-se de sua filha. Esta havia sido eleita por Paraguaçu, entre outras filhas de caciques, para acompanhá-la à França, onde Paraguaçu seria batizada, tomando como madrinha Catarina de Médices (sic). O velho cacique, assim como Gupeva (ao qual a jovem estava prometida em casamento) que o acompanhava, chorava por causa da despedida, mesmo sendo a ausência da jovem donzela, de nome Épica, relativamente curta ${ }^{\text {xxiv }}$. O velho pai de Épica, cegado pelos anos, demandava-lhe insistentemente se sua filha havia retornado. Ao ouvir o não do jovem guerreiro, seguia cabisbaixo, torturado por suas saudades. O jovem guerreiro, que tinha plena certeza do retorno breve de Épica, começa também a se angustiar com a espera. Até que, finalmente, um navio chega trazendo Paraguaçu e Épica de volta para o Brasil. Ambos vão saudá-las e, enquanto o velho cacique, cego, chora emocionado por ter sua filha de volta, um outro sentimento toma conta do jovem guerreiro que o conduz ao encontro da filha:

Épica, a jovem índia, trajava ricos vestidos à européia. Apertava-lhe a cintura delgada, e flexível, como a palmeira do deserto, um cinto negro de veludo, e as amplas dobras do seu vestido branco envolviam-lhe corpo mimoso, delgado, como a haste da açucena à beira-rio. As tranças negras de azeviche, que lhe molduravam as faces aveludadas, eram aqui e ali entremeadas de flores artificiais. Era todo artifício aquele trajar até então desconhecido do moço índio; ele sentiu repugnância em ver aquela que era tão simples no meio da solidão, ornar-se agora de trajes, que faziam desmerecer sua beleza e seus encantos (DOS REIS, 1975:114)

A risonha esposa de Caramuru, a Paraguaçu, chega ao Brasil com o semblante pleno de saudades da terra natal; atrás dela vinha Épica, sem entusiasmo e calada. A jovem Épica abraça o pai, mas continua muda. Ao pedido de seu pai, ela volta o olhar ao seu prometido, e no mesmo instante se desfaz a má impressão que as vestes à européia lhe tinham causado. Chega então o dia do casamento de Épica e do jovem guerreiro. Dado que Épica, juntamente com Paraguaçu, tinha recebido o batizado e se convertido ao cristianismo, a cerimônia de casamento é celebrada por um sacerdote cristão, e o jovem guerreiro se converte também ao cristianismo. Mas no momento final da cerimônia, quando falta apenas o "sim" de Épica para finalizar a união, esta cai desmaiada. Finalmente, quando esta volta a si, confessa a Gupeva que se apaixonara por um homem na França:

- Oh! é preciso que me escutes até o fim, depois mata-me.

Esquecida, prosseguiu Épica, de que o homem de suas afeições chamava-se Conde de... — Gupeva, eu cometi uma falta, que mais tarde deveria cobrir de opróbio o homem que me recebesse por esposa. $\mathrm{O}$ amor não prendeu o coração do conde, ele esqueceu os extremos de meus afetos, e desposou uma donzela nobre de sua nação, sem sequer comover-se das minhas lágrimas (DOS REIS, 1975:117).

Quando Épica descobriu o amor do conde por outra mulher, já trazia em seu ventre um filho. E, nesse ponto da narrativa, o cacique que está a narrar a história de Épica para Gastão confessa ser ele aquele jovem guerreiro. O velho cacique é Gupeva, o bravo índio que, por ocasião do primeiro dia de seu casamento, "acabara de receber a mulher impura, e maculada pelo filho da Europa" (id. ibid.) Apesar de toda a dor, o velho Gupeva decide tomar conta do fruto do ventre indígena profanado pela homem europeu. E a jovem nascida do encontro dessa índia com o Conde de... Gupeva batizou Épica, tal como a mãe. A filha de Épica e do Conde de... é a jovem pela qual Gastão se apaixonou.

Nesse momento, Gastão empalideceu. Reconheceu em Conde de... o seu próprio pai. Gupeva, acusando Gastão de infame ao declarar-se "o filho do sedutor de vossa esposa" (idem: 118), fere de morte o jovem francês. Desta forma, a paixão de Gastão por Épica se configura duplamente como destinada ao trágico: primeiramente, pela fronteira racial, o que deslegitima a união frente aos valores europeus (até mesmo Alberto, amigo de Gastão, coloca-se contra esse idílio); e, finalmente, por estar esse amor sob as marcas do incesto, visto serem Gastão e Épica meio-irmãos. Diferentemente do Édipo-Rei de Sófocles, a união incestuosa não se concretiza, sendo Gastão punido com a morte antes da união consumada com Épica.

Nesse momento, Épica entra em cena, e ao ver seu amado estirado ao chão, pergunta a Gupeva porque assassinara seu amado. Prostrado, Gupeva nada diz. A jovem índia joga-se sobre o corpo inerte do amado que, segundos antes da morte, ainda tem fôlego para falar; "Épica, eu sou teu irmão..." (DOS REIS, 1879:119). O dia amanhece e Alberto, pressentindo terríveis acontecimentos, comunica ao comandante do navio sua preocupação. Um grupo sai do navio em missão de busca e, ao chegar ao bosque, depara-se com uma cena terrível:

Sentado no tronco de uma árvore estava um velho tupinambá; brandia em suas mãos um tacape ensangüentado; a seus pés estavam dois cadáveres!... reclinadas ambas as faces para a terra, Alberto não pôde reconhecer seu amigo senão pelo uniforme da marinha, que o sangue tingira, e que as águas, que se desprenderam à noite, haviam ensopado e enxovalhado. $\mathrm{O}$ outro cadáver era o de uma mulher... Bela devia ser ela, porque seus cabelos longos, e ondeados, fáceis aos beijos da viração da tarde, esparsos assim sobre o seu corpo, davam-lhe o aspecto de uma Madalena (DOS REIS, 1975:120).

Ao contemplarem tal quadro, Alberto e seus companheiros providenciam sepultura para os dois jovens. A 
semelhança entre ambos é tanta que mesmo Alberto observa que só poderiam ser irmãos, tão parecidos eram. Apenas quando finalizam o improvisado rito fúnebre é que se lembram do velho; ele está morto estirado ao chão. Enquanto o velho Gupeva brandia enlouquecidamente seu tacape, comemorando enlouquecido a sua vingança contra o filho do sedutor de sua prometida, o mesmo lhe escapa das mãos, ferindo-o de morte.

Como já foi visto anteriormente, por ocasião da análise do romance D. Narcisa de Villar, as estratégias narrativas são cruciais para se dar voz aos personagens com filiações de raça e gênero destoantes da matriz hegemônica de identidade nacional. No romance de Castro, a estratégia utilizada pela autora lança mão de um recurso metadiagético inusitado: remeter as narradoras originais da história (Mãe Micaela e Simoa) a um espaço fora e além do universo diegético, um espaço atemporal e confortável no qual Taim trava conhecimento da fábula que conta a história de amor entre D. Narcisa e Leonardo. Taim, encantada com a beleza do relato, fixa-o como escritura, legitimando a voz das duas índias ao transcrever a visão delas para a cultura letrada. Formalmente, Castro lança mão de elementos que extrapolam o universo diegético no qual a narrativa se desenvolve, pois cria uma ruptura metaléptica entre um primeiro nível diegético (a história que deu origem à lenda da Ilha do Mel), e um outro, extradiegético, que dá conta de explicitar ao leitor o porquê de se estar contando essa história. De acordo com Gérard Genette,

...todos esses jogos metalépticos manifestam, pela intensidade dos seus efeitos, a importância do limite que se esforçam por transpor [...] fronteira oscilante mas sagrada entre dois mundos. [...] Aquilo que na metalepse é mais perturbador está de fato nessa hipótese inaceitável e insistente de que o extradiegético é talvez sempre já diegético, e que o narrador e seus narratários, quer dizer, eu, vós, pertencemos ainda a alguma narrativa (1995:235).

Maria Firmina dos Reis, diferentemente de Castro, não chega a criar uma ruptura tão radical, ainda que se utilize também de estratégias narrativas bem interessantes. Ao invés de operacionalizar uma voz narrativa branca que se dispõe a registrar um relato oral, dos Reis vai utilizar estratégias de encaixe narrativo sem, no entanto, extrapolar o espaço no qual as ações acontecem. Através da voz de Gupeva, Maria Firmina realiza um movimento descrito por Genette como analepse: a volta a um tempo passado, anterior ao presente narrativo, possibilitando o acesso a eventos anteriores e a compreensão de eventos aparentemente sem sentido através de uma relação causal estabelecida entre o passado (acessível via analepse) e o presente enunciativo da narrativa ${ }^{\mathrm{xxv}}$.

O velho índio Gupeva, pai de Épica, ao inserir na diegese narrativa acontecimentos ocorridos em um tempo outro, distante do personagem Gastão, insere uma nova série de eventos que se configuram como causa dos eventos acontecidos na primeira instância narrativa (o presente enunciativo no qual atua o personagem Gastão). Serão estes eventos visibilizados pela analepse que permitirão a Gastão descobrir que é meio-irmão de Épica. Assim, mais do que permitir que o índio assuma o locus de enunciação durante a narrativa, a narração analéptica, ao desvelar mazelas pertencentes ao passado, vai encaminhar a narrativa para o seu desfecho, culminando com a morte de Épica, Gastão, e do próprio Gupeva. É a partir daqui que se torna possível a observação dos elementos trágicos subliminares às narrativas de Castro e dos Reis, elementos que não são apenas "temáticos" (a violência, o assassinato e o incesto), mas também de cunho formal, se pensarmos, por exemplo, nos elementos formais do trágico grego tal como foram pensados por Aristóteles, o primeiro pensador a esboçar uma "teoria do trágico".

No Capítulo XI de sua Arte Poética, Aristóteles detém-se sobre os elementos da ação trágica complexa: a peripécia, o reconhecimento e a catástrofe (esta última também conhecida como acontecimento patético). A peripécia é definida como "a mudança da ação no sentido contrário ao que foi indicado" (ARISTÓTELES, [s.d.]: 255), ou seja, o momento no qual há uma inversão no encaminhamento dos acontecimentos, de forma a conduzir o desenvolvimento da ação para o final trágico (normalmente, a chave que desencadeia a peripécia é a hybris, a desmedida, o momento no qual o herói trágico ultrapassa o métron, a medida de sua própria humanidade). $\mathrm{O}$ reconhecimento, "como o nome indica, faz passar da ignorância ao conhecimento, mudando a amizade em ódio ou inversamente nas pessoas votadas à felicidade ou ao infortúnio" (id. ibid.); é o momento no qual o enredo trágico é evidenciado e, muitas vezes, é aí onde o herói toma conhecimento de sua própria desmedida: "O mais belo dos reconhecimentos é o que sobrevém no decurso de uma peripécia" (id. ibid). Finalmente, o acontecimento patético é o resultado de "uma ação que provoca a dor ou o sofrimento, como as das mortes em cena, das dores agudas, dos ferimentos e outros casos análogos" (id. ibid.). É em função da nêmesis, (a vingança dos deuses), que se segue à hybris como punição que o acontecimento patético surge e explicita sua função dentro da tragédia: reestabelecer uma ordem transcendental e superior, que foge ao conhecimento dos personagens trágicos.

Pode-se identificar, dentro das narrativas indianistas aqui analisadas, a presença dos elementos da ação complexa sistematizados por Aristóteles. Tanto Castro quanto dos Reis utilizam-se de um esquema que salienta o caráter trágico do encontro entre duas raças. As narrativas de ambas as escritoras, que em um primeiro momento lembram o script narrativo alencariano, logo em seguida deslizam para um outro esquema narrativo, onde os traços trágicos dão uma nova significação para a impossibilidade de um amor realizado entre dois sujeitos coloniais pertencentes a raças diferentes. Como afirma Albi Lesky, "com o adjetivo 'trágico' designamos uma maneira muito definida de ver o mundo" (LESKY, 1990:21).

A peripécia em $D$. Narcisa é o momento no qual seus irmãos decidem entregá-la aos cuidados de um 
coronel português, com vistas a, ao mesmo tempo, manter a herança exclusivamente nas mãos dos três irmãos, e ainda acrescentar algum capital a título de dote. Tal peripécia inverte o rumo dos acontecimentos (até aqui era possível supor que haviam possibilidades do amor entre Narcisa e Leonardo se realizar), levando à fuga dos enamorados, a perseguição e finalmente o assassínio dos amantes pelos irmãos de Narcisa, um acontecimento nitidamente patético, nos termos estritos nos quais Aristóteles o descreveu:

- Ah! exclamou a moça exaltando-se: não me consultaram; sou eu a única que tudo ignoro de um fato que sabe-lo-á talvez até o mais obscuro dos criados que me servem, porque dispuseram de mim um fardo, que se mercadeja!... Se querem agora a minha presença, é para que o comprador veja melhor a qualidade do estofo que ajustou pelo preço que se chama dote! Ah! e querem, depois de toda esta profanação do mais sagrado de todos os atos da vida da mulher, que haja casamentos felizes?... Irrisão!... (CASTRO, 1990:49).

Finalmente, há o reconhecimento: Efigênia revela que Leonardo é primo-irmão de Narcisa:

Viu-se então entrar pela gruta uma mulher alta [Efigênia], de braços nus, toda desgrenhada, e cujos vestidos molhados estavam na maior desordem.

- Suspende, monstro! disse ela encarando o assassino com majestade; não cometas um novo crime, não mates teu filho!..

— Meu filho?!... respondeu, levantando-se, D. Luís (CASTRO 1990:77).

Em Gupeva, a presença dos traços trágicos também ocorre: no momento em que Gastão vai ao encontro de Épica, depara-se com Gupeva. Após o conflituoso encontro, Gupeva começa a relatar sua história (Capítulo III). Ao terminá-la, a possibilidade do incesto desvela-se (reconhecimento), como se pode observar neste trecho: — Da minha vingança serás tu a primeira vítima - continuou o cacique; mais tarde o Conde de...

- Eis-me aqui, disse Gastão, interrompendo. Gupeva, eu sou filho do Conde de..., não me reconheceste então? Oh! eu sou francês, sou o filho do sedutor de vossa esposa, sou irmão de Épica...

— Infame! rugiu o velho tupinambá. Infame filho do Conde de..., não terei compaixão de ti. E brandindo seu tacape, o cravou com fúria no peito do jovem oficial. E batia com os pés na terra, e fazia com gritos um alarido infernal (DOS REIS, 1975:118).

A peripécia está atrelada ao surgimento inesperado de um personagem que colocará em cena uma ruptura de cunho analéptico na narrativa, a partir da qual o reconhecimento também se dá: ao ouvir a história de Gupeva, Gastão se reconhece como o filho do Conde de..., que violou a mãe de Épica, a prometida de Gupeva. Sendo meio-irmãos, a união é mais uma vez impossibilitada, e Gupeva termina por assassinar Gastão e a própria Épica, filha de sua prometida, e a quem se comprometeu a aceitar como sua própria filha. Por fim, o próprio Gupeva, enlouquecido, acidentalmente fere a si mesmo de morte com o tacape utilizado para assassinar os enamorados.

É extremamente pertinente perguntar qual a motivação encontrada por estas escritoras para lançarem mão de tantos recursos típicos da tragédia ática. Partindo da afirmação já mencionada de Lesky (a de que o adjetivo trágico, muito mais do que um gênero literário, define um modo muito particular de ver o mundo), é possível levantar algumas possíveis respostas para a indagação em torno da utilização de elementos trágicos pelas escritoras do século XIX.

\section{CONSIDERAÇÕES FINAIS: RECONSIDERANDO A IDENTIDADE NACIONAL ATRAVÉS DE ELEMENTOS TRÁGICOS}

Aristóteles, em suas reflexões sobre a tragédia clássica, define duas tríades de elementos constitutivos da mesma. A primeira dessas tríades diz respeito às unidades de tempo, de espaço e de ação. A segunda delas é definida no momento em que ele se detém sobre os elementos da ação complexa: peripécia, reconhecimento e catástrofe (ou acontecimento patético). Na narrativa de dos Reis toda a ação ocorre no período que vai do deitar do sol ao amanhecer. D. Narcisa de Villar, por sua vez, ainda que apresente algumas digressões como, por exemplo, algumas informações sobre a infância de Narcisa, traz o cerne de sua fabulação também em um período que vai do anoitecer aos primeiros raios de sol. Basta lembrar que a ação propriamente dita de Castro vai do momento do casamento de Narcisa com o coronel português, terminando com o assassinado de Narcisa e Leonardo na Ilha do Mel.

Da mesma forma, as unidades de tempo e espaço também são mantidas: basta que se relativize um pouco a definição destas categorias. Mesmo nas tragédias clássicas, há a presença de elementos narrativos que fogem a uma idéia estrita dessas unidades, e mesmo quando estes estão extremamente atreladas a essas unidades, é importante lembrar que a fábula das tragédias estava baseada nos mitos gregos. Desta forma, a representação do espaço e do tempo na tragédia não necessitava de uma contextualização, que traria os antecedentes do momento específico que estava sendo representado, visto que tais informações estavam disseminadas na cultura clássica; essas não precisavam ser incluídas na diegese trágica pois eram de domínio público:

O homem, em seu trágico destino, não pode fazer outra coisa senão gritar, não se lamentar nem se queixar, mas gritar a plenos pulmões aquilo que nunca foi dito, aquilo que antes talvez nem se soubesse, e para nada: somente para dizê-lo a si mesmo, para ensinar a si mesmo (LESKY, 1990:27).

A utilização dos elementos da segunda tríade aristotélica, entretanto são os de maior importância para a politização do trágico. Se não resta ao homem, frente ao seu trágico destino, gritar coisas que nunca foram ditas, 
as escritoras do século XIX o fazem sistematicamente. Frente a um processo de escritura da nação que silenciou mulheres e índios, tais escritoras gritaram a plenos pulmões que a identidade nacional não era una, que o projeto de construção de um imaginário nacional a partir do idílio inter-racial era uma farsa, e que todos os que não se submetessem aos desígnios dos senhores portugueses eram exterminados. Através do redimensionamento da peripécia e da catástrofe, mais do que encenar o drama do colonialismo, dos Reis e Castro politizam o patético, mostrando uma função não apenas catártica para o mesmo, mas também uma função de denúncia. Se o patético vai, na tragédia clássica, punir a hybris do herói trágico, colaborando para a manutenção do status quo da pólis grega, nos textos indianistas de autoria feminina esse mesmo elemento vai figurar como estratégia de enunciação, permitindo a enunciação da diferença e mostrando a violência decorrente das tentativas de apagamento das especificidades de raça e de gênero.

O reconhecimento - que em ambas as narrativas analisadas vai dar conta da descoberta de uma relação incestuosa $^{\mathrm{xxvi}}$ - pode parecer a princípio apenas uma estratégia moralista que justifica a morte do par romântico. Entretanto, ele ultrapassa essa função para denunciar a violência erótico-sentimental que os europeus exerceram sobre as indígenas brasileiras. Ora, D. Luís tem um filho com Efigênia, e pelo caráter despótico que a narradora atribui aos três irmãos portugueses em D. Narcisa de Villar, pode-se imaginar de que natureza foi o contato sexual entre ambos. $\mathrm{O}$ fato de Efigênia manter em segredo a paternidade do filho também é uma estratégia de resistência, pois ela perderia todos os direitos sobre o filho para D. Luís (da mesma forma que aconteceu com a Iracema alencariana, privada de contato com seu filho Moacir).

Nas narrativas destas escritoras, tal como visto anteriormente, há uma característica marcante, que é a utilização de elementos dramáticos - típicos da tragédia clássica - no desenvolvimento de suas tramas romanescas. Particularmente na obra de Maria Firmina dos Reis, a tônica sobre os elementos trágicos é bastante acentuada. Tendo em vista que o deslocamento e utilização dessas estratégias normalmente associadas ao trágico por dos Reis e Castro salienta a violência do embate colonial, minha afirmação é a de que, ao inserir elementos trágicos no idílio indianista, essas escritoras não apenas os politizam, mas também redimensionam todo o significado da narrativa fundadora, na medida em que tais elementos não estão aqui aplicados com vistas a suscitar sentimentos catárticos, mas para denunciar a violência real, de cunho físico e cultural, sofrida pelos povos indígenas.

É graças à inserção de elementos trágicos que se torna possível visibilizar os processos de opressão sofridos por mulheres e índios. Mais do que um genocídio, um ginocídio e um etnocídio, um silenciamento que torna a identidade nacional monolítica, ou ainda um sinal de menos-na-origem que, quando recuperado, não apenas soma, mas desestabiliza completamente a lógica do próprio cálculo. Lesky, ao refletir sobre o "conflito trágico cerrado", responsável por levar a tragédia ao desfecho patético, catastrófico, levanta as seguintes questões:

Mas agora em primeiro plano coloca-se a seguinte questão: quando, no conflito trágico cerrado, somos testemunhas da destruição do protagonista sofredor, será só isto que o autor é capaz de nos mostrar? Será que nenhuma de suas palavras nos levará além da ação terrível, para um mundo em que há ordem e sentido? Ele nos deixa sair com a sensação de aniquilamento, ou espera que, com fria concordância passiva, nos conformemos com um mundo que se dirige para a destruição, e nada além da destruição? Ou será que, pelo exemplo trágico, ele nos eleva até a consciência de que tudo isso acontece sob o signo de um mundo de normas e valores absolutos, um mundo que permite ao homem conservar o que não pode ser perdido, nem mesmo em meio às trágicas tempestades? (LESKY, 1990:45).

"Será que nenhuma de suas palavras nos levará além da ação terrível, para um mundo em que há ordem e sentido?" Não saberia responder tal questão pensando nas obras trágicas da Grécia Clássica mas, ao analisar a dramatização do idílio nos escritos indianistas de autoria feminina, fica clara a filiação ideológica ${ }^{\text {xxvii }}$ dessas autoras, o que permite responder à pergunta de Lesky. Mais do que nos levar à ação terrível, as obras de dos Reis e Castro redimensionam o significado da catástrofe trágica. Ela não vai "purgar” o público leitor de folhetins do século XIX através de assassinatos e incestos, mas sim denunciar as operações discursivas que invisibilizam a experiência histórica de sujeitos marginalizados, tais como mulheres e índios. Assim, acredito ter alcançado a resposta da questão que deixei em suspenso no início desse trabalho: por que tais obras foram ignoradas pela crítica?. Porque tocam em questões que desestabilizam o imaginário em torno da nação e da brasilidade, imaginário esse que estava em pleno processo de elaboração na metade do século XIX, período no qual tais obras foram publicadas.

A partir da leitura de dois romances indianistas escritos por mulheres, torna-se clara não apenas a divisão entre as "duas historiografias" às quais Edward Said se refere em Cultura e Imperialismo, mas também suas conseqüências refratadas no trabalho de crítica literária: uma perspectiva "linear e dominadora", que vê ainda a produção cultural da nação com um certo anacronismo beletrista, e uma outra, "contrapontual e muitas vezes nômade"xxviii, que realiza suas reflexões a partir das fissuras nos alicerces monolíticos das concepções de cultura nacional. Penso ter conseguido explicitar minha filiação a esta segunda maneira de pensar a cultura e a literatura.

Assim, recuperando algumas das noções já expostas, pretendo neste momento trazer à tona a maneira pela qual os romances $D$. Narcisa de Villar e Gupeva deslocam a maneira de pensar a identidade nacional, assim como a nova perspectiva adotada por Maria Firmina dos Reis e Ana Luísa de Azevedo Castro para narrar o 
encontro colonial entre americanos e europeus em terras brasileiras. Para tanto, adoto uma estratégia intertextual que coloca não apenas esses dois romances em cotejo, mas que também estabelece um diálogo com os romances indianistas celebrizados, identificando estratégias formais e temas abordados tanto nas narrativas consagradas pelo cânone quanto nestas outras por ele silenciadas, tentando identificar os motivos que levaram a crítica a não se deter sobre as duas narrativas de autoria feminina.

Tanto em $O$ Guarani quanto em Iracema é possível averiguar que, por trás do projeto estético alencariano, há um comprometimento com outros interesses: entre eles, talvez o mais visível seja o de, através da literatura, "escrever a nação", partindo de elementos americanos, com vistas a incorporar ao imaginário nacional a idéia de uma nação democrática - afinal, tanto índios quanto brancos participaram das suas narrativas fundadoras - e com filiações étnicas autóctones e européias. Mas, se por um lado, Peri se mostra um cavalheiro cortês a auxiliar Dom Antônio de Mariz e a amar platonicamente Cecília, e Iracema uma leal serva e um fértil ventre a ser semeado por Martim, por outro se esquece justamente daquilo que esses dois personagens não fazem: por mais que tenham sido violentamente dizimados por ocasião da ideologia colonial, jamais se poderia afirmar que não ofereceram resistência. Tal como afirma Edward Said:

O contato imperial nunca consistiu na relação entre um ativo intruso ocidental contra um nativo não ocidental inerte ou passivo; sempre houve algum tipo de resistência ativa e, na maioria esmagadora dos casos, essa resistência acabou preponderando (SAID, 1995:12).

Ora, obviamente não podemos ser tão inocentes a ponto de imaginar que os índios brasileiros não foram massacrados pela violência colonialista. Entretanto, também não podemos negar que houve resistência em várias frentes, ainda que em tempos nos quais a violência física já havia deixado cicatrizes irrecuperáveis. As mulheres que escreveram durante o século XIX, diferentemente dos homens, possuíam uma experiência de marginalização e exclusão social que as deixava mais aguçadas para observarem o processo colonial de um outro lugar, de um lugar não hegemônico: foi esse lugar que permitiu a elas se solidarizarem com os índios e escrever uma outra versão para o idílico encontro inter-racial que fundou a raça brasileira.

E, desse outro lugar, puderam elas averiguar e registrar uma outra perspectiva sobre a fundação mítica da nação brasileira, fundação essa calcada não em um lépido e equilibrado intercurso entre Peris e Cecílias, entre Iracemas e Martins. Com personagens como o jovem Leonardo, fruto ele próprio do intercurso sexual entre um nobre português e uma índia, ou a jovem Narcisa, que mesmo sendo branca, portuguesa e abastada, estava tão ou mais colonizada do que as terras administradas por seus irmãos, tão ou mais oprimida do que o mestiço Leonardo. Aliás, torna-se muito pertinente perguntar por que o mestiço Moacir é legitimado como representante da nação, como cidadão nacional, enquanto Leonardo é não apenas taxado de bastardo, mas também assassinado pelo próprio pai e pelos tios.

Ora, pense-se nas filiações identitárias desses dois híbridos, e a questão começa a se tornar compreensível. Moacir, antes de tudo, é desligado de Iracema. Isso não significa apenas uma separação entre mãe e filho, mas uma separação do filho de todos aqueles valores aos quais a identidade de sua mãe estava atrelada. Ainda que Iracema participe do processo, ela não passa de um ventre fértil cuja função não é mais do que nutrir o filho do colonizador; ao pequeno Moacir não é dado o direito de herdar os valores de sua mãe, nem do povo que ela representa. Seus antepassados são esquecidos em nome da filiação a um heróico e bravo português; a religião de sua mãe e seus avós é silenciada: mesmo o guerreiro Poti, ao final da narrativa alencariana, abandona sua religião, seus costumes e mesmo seu nome, adotando a cultura e os valores brancos, tornando-se um subserviente companheiro de Martim. O preço da existência indígena no mundo colonial é a aculturação.

Leonardo, ao contrário de Moacir, não está ligado à herança branca dos valores paternos. Criado por sua mãe Efigênia, pode receber os valores autóctones americanos em sua formação, ao contrário de Moacir, a quem não foi dada nem mesmo a oportunidade de conhecer sua mãe. A filiação de Leonardo aos valores maternos não o legitima como um representante nacional, visto que Dom Luís não reconhece sua paternidade. Finalmente, é possível denunciar a falácia do idílio inter-racial: as índias não colaboram no processo de fundação mítica da nação a não ser como corpos colonizados. Seus valores, os valores dos povos verdadeiramente americanos, não são em nenhum momento assimilados pelos seus filhos, representantes da nova raça brasileira. E, nos raros casos em que tal transmissão-assimilação da herança cultural indígena ocorre, há o despótico assassinato do sujeito social que, ao mesmo tempo, carrega a legitimidade da raça branca e os valores indígenas (o personagem Leonardo do romance de Castro).

Avançar no conhecimento que se tem sobre o passado significa redimensionar, no presente, os nossos conceitos de literatura e cultura, para projetar uma visão de cultura dialógica e plural que, efetivamente, expresse o choque dos valores e encene a diferença como marca de mobilidade permanente do coletivo e das identidades sociais, culturais, nacionais e literárias. Importante salientar que este trabalho não se pretende conclusivo; ao contrário, é o início de uma série de reflexões a serem feitas, pois torna clara a impossibilidade de continuar a pensar a "nação literária" como uma totalidade pré-definida pela tradição canônica. 


\section{REFERÊNCIAS BIBLIOGRÁFICAS}

ALENCAR, José Martiniano de. Iracema: lenda do Ceará. São Paulo: Ática, [s.d.]

O Guarani. 19. ed. São Paulo: Ática, 1995.

ALTHUSSER, Louis. Ideologia e Aparelhos Ideológicos do Estado. Lisboa: Presença; Martins Fontes, 1974.

ANDERSON, Benedict. Nação e Consciência Nacional. São Paulo: Ática, 1989.

ARARIPE JUNIOR, Tristão de Alencar. Araripe Junior: Teoria, Crítica e História Literária. Rio de Janeiro: Livros Técnicos e Científicos; São Paulo: USP, 1978.

ARISTÓTELES. Arte Poética. Rio de Janeiro: Ediouro, [s.d.].

AUSTIN, J. How to do things with words. Cambridge: Harvard University Press, 1975.

BAKHTIN, Mikhail. Problemas da Poética de Dostoiévski. Rio de Janeiro: Forense Universitária, 1981.

BELLEI, Sérgio Prado. Nacionalidade e Literatura: os caminhos da alteridade. Florianópolis: UFSC, 1992.

BHABHA, Homi K. O Local da Cultura. Belo Horizonte: UFMG, 1998.

BOSI, Alfredo. História Concisa da Literatura Brasileira. São Paulo: Cultrix, 1994.

BOURDIEU, Pierre. O Poder Simbólico. 3. ed. Rio de Janeiro: Bertrand Brasil, 2000.

CANDIDO, Antonio. Formação da Literatura Brasileira: momentos decisivos. São Paulo: Martins, 1964.

CASTRO, Ana Luísa de Azevedo. D. Narcisa de Villar: legenda do tempo colonial pela Indígena do Ipiranga. 2. ed. Florianópolis: Semprelo, 1990.

CULLER, Jonathan. Sobre a Desconstrução. Rio de Janeiro: Record; Rosa dos Tempos, 1997.

DERRIDA, Jacques. A Estrutura, o Signo e o Jogo nas Ciências Humanas. In: A Escritura e a Diferença.

São Paulo: Perspectiva, 1971. p. 227-249.

DUARTE, Constância Lima. A Lágrima de um Caeté: uma nova página do indianismo brasileiro. In: AUGUSTA, Nísia Floresta Brasileira. A Lágrima de um Caeté. 4. ed. Natal: Fundação José Augusto, 1997. p. 7 31 .

O Cânone e a Autoria Feminina. In: SCHMIDT, Rita Terezinha (org.) Mulheres e Literatura: (trans)formando identidades. Porto Alegre: Palloti, 1997. p. 53-60.

EAGLETON, T. Marxism and Literary Criticism. Berkeley; Los Angeles: University of California Press, 1976.

. Teoria da Literatura. São Paulo: Martins Fontes, 1983.

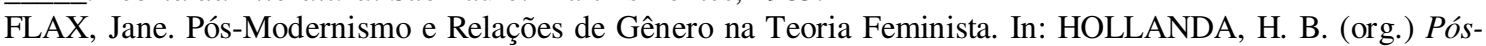
Modernismo e Política. Rio de Janeiro: Rocco, 1991. p. 217-50.

FRANCO, Jean. Sentido e Sensualidade: notas sobre a formação nacional. In: HOLLANDA, H. B. Tendências e Impasses. Rio de Janeiro: Rocco, 1994. p. 99-126.

GENETTE, Gérard. Voice. In. LANDA, Susana \& ONEGA, José Angel García. Narratology: an introduction. London \& New York: Longman, 1996.

GOMES, Heloísa Toller. A Questão da Nacionalidade, Relações Sociais e Código Erótico na Literatura Brasileira Oitocentista. In: Literatura e Diferença: Anais do IV Congresso da ABRALIC. São Paulo: ABRALIC, 1995. p. 387-92.

HALL, Stuart. A Identidade Cultural na Pós-Modernidade. 4. ed. Rio de Janeiro: DP\&A, 2000.

HOLANDA, Sergio Buarque de. Visão do Paraíso. São Paulo: Brasiliense; PubliFolha, 2000.

HOLlandA, Heloísa Buarque de (org.) Pós-Modernismo e Política. Rio de Janeiro: Rocco, 1991.

. Tendências e Impasses: o feminismo como crítica da cultura. Rio de Janeiro: Rocco, 1994.

JOBIM, José Luis (org.) Palavras da Crítica. Rio de Janeiro: Imago, 1992.

LEMAIRE, Ria. Relendo Iracema: o problema da representação da mulher na construção de uma identidade nacional. ORGANON: Revista da Faculdade de Filosofia da Universidade Federal do Rio Grande do Sul. Porto Alegre, v. 16, nº. 16, p.257-279, 1989.

LOPES, Cristina e REIS, Carlos. Dicionário de Teoria da Narrativa. São Paulo: Ática, 1988.

LYRA, Pedro. Ideologia. In: JOBIM, J. L. Palavras da Crítica. Rio de Janeiro: Imago, 1992. p. 151-184.

MARX, K. e ENGELS, F. O Materialismo Histórico e as Superestruturas Ideológicas. São Paulo: Global, 1979. MONTAIGNE. Montaigne. v. I. São Paulo: Nova Cultural, 2000.

MUZART, Zahidé Lupinacci. Uma Catarinense na Literatura do Século XIX. In: CASTRO, Ana Luísa de Azevedo. D. Narcisa de Villar: legenda do tempo colonial pela Indígena do Ipiranga. Florianópolis: Editora Semprelo, 1990. p. IX-XVI.

(Org.) Escritoras Brasileiras do Século XIX. 2. ed. Florianópolis; Santa Cruz do Sul: Mulheres; EDUNISC, 2000.

Maria Firmina dos Reis. In: . (org.) Escritoras Brasileiras do Século XIX. 2. ed. Florianópolis; Santa Cruz do Sul: Mulheres; EDINISC, 2000. p. 264-284.

Ana Luísa de Azevedo Castro. In: ___ (org.) Escritoras Brasileiras do Século XIX. 2. ed. Florianópolis;Santa Cruz do Sul: Mulheres; EDUNISC, 2000. p. 250-63.

ORLANDI, Eni (org.) Discurso Fundador: a formação do país e a construção da identidade nacional. Campinas: Pontes, 1993. 
PETERSON, Michel. Estética e Política do Romance Contemporâneo. Porto Alegre: Editora da UFRGS, 1995. PRATT, Mary Louise. Mulher, Literatura e Irmandade Nacional. In: HOLLANDA, Heloísa Buarque de. Tendências e Impasses. Rio de Janeiro: Rocco, 1994. pp.127-57.

QUEIROZ, Vera. Crítica Literária e Estratégias de Gênero. Niterói: EDUFF, 1997.

REIS, Maria Firmina dos. Úrsula. Rio de Janeiro: Presença, 1988.

Gupeva: romance brasiliense. In: MORAIS FILHO, José Nascimento. Maria Firmina: fragmentos de uma vida. São Luís: Imprensa do Governo do Maranhão, 1975. p. 103-134.

. A Escrava (conto). In: MORAIS FILHO, José Nascimento. Maria Firmina: fragmentos de uma vida. São

Luís: Imprensa do Governo do Maranhão, 1975. p. 123-34.

ROUSSEAU. _. Rousseau. v. I. São Paulo: Nova Cultural, 2000.

SCHMIDT, Rita (org.) Mulheres e Literatura: (trans)formando identidades. Porto Alegre: Palloti, 1997.

Em busca da história não contada ou: o que acontece quando o objeto começa a falar? Revista Letras. Santa Maria, n 16 , p.183-96, 1998.

Os estudos literários como campo de investigação: paradigmas e desafios. Cadernos do IL. Porto Alegre, no 20 , p. 85-92, dez. 1998.

SOMMER, Doris. Amor e Pátria na América Latina. In: HOLLANDA, Heloísa Buarque de. Tendências e Impasses. Rio de Janeiro: Rocco, 1994. p. 158-83.

SOUSA, J. Galante de. Duas escritoras e um problema de autoria. In: Machado de Assis e outros escritos. Rio de Janeiro: Cátedra; Brasília: INL, 1979. p. 217-20.

Notas:

${ }^{\mathrm{i}}$ REIS, Maria Firmina dos. Gupeva: romance brasiliense. Publicado pela primeira vez no jornal O Jardim dos Maranhenses (entre $1961 \mathrm{e}$ 1962). O romance é republicado em 1863 no jornal Eco da Juventude, e transcrito integralmente em MORAIS FILHO, José Nascimento. Maria Firmina: fragmentos de uma vida. São Luís: Imprensa do Governo do Maranhão, 1975.

ii A esse respeito, conferir SCHMIDT, Rita Terezinha. Em busca da história não contada ou: o que acontece quando o objeto começa a falar? Revista Letras, n $^{\circ}$ 16, p. 183-96, 1998.

iii Ainda que estes textos já tenham sido resgatados e republicados, vale ressaltar que é a partir do discurso crítico que as representações culturais são incorporadas no rol do que é legível pela comunidade letrada. Assim, o trabalho de reflexão crítica sobre tais textos colabora com o trabalho resgate na medida em que tenta inserir tais textos dentro da série literária canonizada pelo discurso crítico-historiográfico, possibilitando uma leitura que rompe, desestrutura e redimensiona o patrimônio literário nacional.

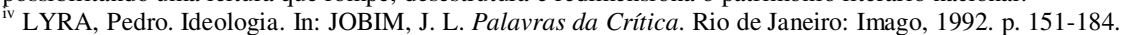

${ }^{v}$ FLAX, Jane. Pós-Modernismo e Relações de Gênero na Teoria Feminista. In: HOLLANDA, Heloísa Buarque de (org.) Pós-Modernismo e Política. Rio de Janeiro: Rocco, 1991. p. 217-50.

${ }^{\mathrm{vi}}$ LOPES, Cristina \& REIS, Carlos. Dicionário de Teoria da Narrativa. São Paulo: Ática, 1988.

${ }^{v i i}$ BAL, Mieke. Narratology: Introduction to the Theory of Narrative. 2nd ed. University of Toronto Press, 1997.

viii GENETTE, Gérard. Voice. In. LANDA, Susana \& ONEGA, José Angel García. Narratology: an introduction. London \& New York: Longman, 1996. pp.172-89.

${ }^{\text {ix }}$ SCHMIDT, Rita Terezinha. Os estudos literários como campo de investigação: paradimas e desafios. Cadernos do IL. n 20, p. 85-92, dez. 1998.

${ }^{x}$ BHABHA, H. K. A Outra Questão: o estereótipo, a discriminação e o discurso do colonialismo. In: O Local da Cultura. Belo Horizonte: UFMG, 1998.

${ }^{x i}$ Conferir MUZART, Zahidé Lupinacci. Uma Catarinense na Literatura do Século XIX. In: CASTRO, Ana Luísa de Azevedo. D. Narcisa de Villar: legenda do tempo colonial pela Indígena do Ipiranga. Florianópolis: Editora Semprelo, 1990. p. IX-XVI.

xii SOUSA, J. Galante de. Duas escritoras e um problema de autoria. In: Machado de Assis e outros escritos. Rio de Janeiro: Cátedra; Brasília: INL, 1979. p. 217-20.

xiii MUZART, Zahidé L. Ana Luísa de Azevedo Castro. In: Escritoras Brasileiras do século XIX. 2. ed. Florianópolis; Santa Cruz do Sul: Mulheres; EDUNISC, 2000. p. 250-63.

xiv ALENCAR, José de. O Guarani. 19. ed. São Paulo: Ática, 1995.

xv GOMES, Heloísa Toller. A Questão da Nacionalidade, Relações Sociais e Código Erótico na Literatura Brasileira Oitocentista. In: Literatura e Diferença: Anais do IV Congresso da ABRALIC. São Paulo: ABRALIC, 1995. p. 387-92.

xvi De acordo com Aristóteles na Arte Poética (Rio de Janeiro: Ediouro, [s.d.]:255), a ação complexa no texto trágico (há o trágico de ação simples, no qual a fábula se desenvolve linearmente) é constituída por três partes: a peripécia ou "mudança de ação no sentido contrário ao que foi indicado" (id. ibid.), o reconhecimento (o momento no qual se passa da ignorância ao conhecimento como, por exemplo, quando Édipo descobre ser filho de Jocasta, levando ao desfecho trágico) e, finalmente, o patético ou catástrofe: "o patético é devido a uma ação que provoca a morte ou sofrimento, como as das mortes em cena, das dores agudas, dos ferimentos e outros casos análogos" (id. ibid.). Baseado nesses três "traços" da ação trágica complexa é que afirmo o caráter trágico de D. Narcisa de Villar (e também de Gupeva, como será visto mais adiante): a peripécia (a não consumação do amor entre o par idílico índio-brasileiro e branca-portuguesa), o reconhecimento (presente tanto em Castro quanto em dos Reis através do incesto entre os amantes, revelado pouco antes da morte do par amoroso) e do patético - ou catástrofe - (o assassinato extremamente violento do casal inter-racial, em ambos os casos - tanto em Castro quanto em dos Reis - realizado por parentes muito próximos - os irmãos, em D. Narcisa, e o próprio pai, em Gupeva.

xvii A autora, em nota de rodapé à última página do prólogo, explica que Taim é um pronome de tratamento indígena e que significa "menina, senhora solteira. É como Mademoi selle dos Franceses, ou Miss dos Ingleses" (CASTRO, 1990:21).

xviii HOLANDA, Sergio Buarque de. Visão do Paraíso. São Paulo: Brasiliense; Publifolha, 2000. (Grandes Nomes do Pensamento Brasileiro).

xix MUZART (2000, p. 264) cita, entre tais jornais, os seguintes: A Verdadeira Marmota, Semanário Maranhense, O Domingo, O País, Pacotilha, Federalista, Eco da Juventude e Porto Livre, entre outros.

${ }^{x x}$ MORAIS FILHO, José Nascimento. Maria Firmina: fragmentos de uma vida. São Luís: Imprensa do Governo do Maranhão, 1975. 
${ }^{x x i}$ MUZART (2000, p. 272) menciona as seguintes composições: Auto de Bumba-Meu-Boi (letra e música); Valsa (letra de Gonçalves Dias e música de Maria Firmina dos Reis); Hino à Mocidade (letra e música); Rosinha (letra e música); Pastor Estrela do Oriente (letra e música) e Canto de Recordação (letra e música).

xxii MUZART, Zahidé. Maria Firmina dos Reis. In: (org.) Escritoras Brasileiras do Século XIX. 2. ed. Florianópolis; Santa Cruz do Sul: Mulheres; EDINISC, 2000. p. 264-284

xxiii Assim descreve a natureza Maria Firmina dos Reis, por ocasião dos primeiros momentos de sua narrativa: "Uma tarde de agosto nas nossas terras do norte, tem um encanto particular; quem ainda as não gozou, não conhece na vida o que há de mais belo, mais poético, não conhece a hora do dia que o Criador nos deu para esquecermos todas as ambições da vida, para folhearmos o livro do nosso passado, buscarmos nele a melhor página, a única dourada que nele existe, e aí nos deleitarmos na recordação saudável da hora feliz da existência (...).” Ou ainda, mais adiante: “(...) porque nessa hora [o ocaso] como que a face do senhor se nos patenteia nos desmaiados raios do sol, no manso gemer da brisa, o saudoso murmúrio das matas, na vasta superfície das águas, na ondulação mimosa dos palmares, no perfume odorífero das flores, no canto suavíssimo das aves, na voz reconhecida da nossa alma!" (DOS REIS, 1975, p. 104) [ grifos meus].

${ }^{\text {xxiv }}$ Importante ressaltar que, na narrativa, há duas personagens de nome Épica. Uma é a jovem pela qual Gastão se apaixona; a outra é mãe desta mesma jovem, a prometida de Gupeva.

${ }^{\mathrm{xxv}}$ Os limites entre as noções metadiegese e metalepse, se vistas descontextualizadas do restante do pensamento de Genette, podem parecer um pouco difusos. Por diegese Genette entende o universo ficcional de uma narrativa (o tempo, o espaço, as leis que o regem, etc.) em sua totalidade. Entretanto, essa totalidade pode ser rompida através de uma instância metadiegética que, grosso modo, pode ser entendida, como "a narração dentro da narração", ou ainda como "a história dentro da história". Já a metalepse é descrita como a passagem de um nível narrativo para outro. O termo fica mais compreensível se comparado com outros análogos, também formulados por Genette, como prolepse (antecipação de um acontecimento da narrativa, por exemplo, por meio de um sonho divinatório), analepse (conhecido em linguagem fílmica como flash-back, a analepse trata de voltar a acontecimentos passados em relação ao presente da narrativa, ainda que tais acontecimentos ainda não tenham sido, em nenhum momento, desvelados pelo narrador ou por algum personagem) e finalmente silepse (a narração simultânea de dois acontecimentos distintos, mas que ocorrem paralelamente em um mesmo espaço de tempo)

xxvi $\mathrm{Na}$ verdade, o reconhecimento não dá conta da relação incestuosa propriamente dita, mas da possibilidade do incesto, visto que os amantes - em ambas as narrativas - são assassinados antes de poderem concretizar o idílio.

xxvii Quando falo em filiação ideológica, não pretendo taxar de panfletárias essas escritoras, por comparação a outros escritores supostamente "neutros". Acredito ter deixado claro que Alencar é também ideológico em seu projeto de construir a nação brasileira através de seus escritos.

xxviii “Antes que possamos concordar quanto aos elementos que compõem a identidade americana, temos de admitir que, enquanto sociedade de colonos imigrantes que se impôs sobre as ruínas de uma considerável presença autóctone, a identidade americana é variada demais para chegar a constituir algo unitário e homogêneo; na verdade, a luta que se trava em seu interior envolve defensores de uma identidade unitária e os que vêem o conjunto como uma totalidade complexa, mas não redutoramente unificada. Essa oposição supõe duas perspectivas diferentes, duas historiografias diversas, uma linear e dominadora, a outra contrapontual e muitas vezes nômade" (SAID, 1995:27-8). 